ARTICLE

\title{
Potentially bioavailable iron produced through benthic cycling in glaciated Arctic fjords of Svalbard
}

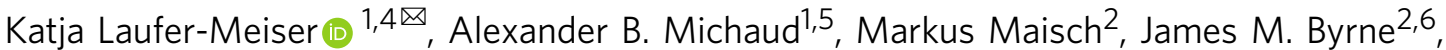 \\ Andreas Kappler (10 4,2, Molly O. Patterson ${ }^{3}$, Hans Røy ${ }^{1} \&$ Bo Barker Jørgensen ${ }^{1}$
}

The Arctic has the highest warming rates on Earth. Glaciated fjord ecosystems, which are hotspots of carbon cycling and burial, are extremely sensitive to this warming. Glaciers are important for the transport of iron from land to sea and supply this essential nutrient to phytoplankton in high-latitude marine ecosystems. However, up to $95 \%$ of the glaciallysourced iron settles to sediments close to the glacial source. Our data show that while $0.6-12 \%$ of the total glacially-sourced iron is potentially bioavailable, biogeochemical cycling in Arctic fjord sediments converts the glacially-derived iron into more labile phases, generating up to a 9-fold increase in the amount of potentially bioavailable iron. Arctic fjord sediments are thus an important source of potentially bioavailable iron. However, our data suggests that as glaciers retreat onto land the flux of iron to the sediment-water interface may be reduced. Glacial retreat therefore likely impacts iron cycling in coastal marine ecosystems.

\footnotetext{
${ }^{1}$ Center for Geomicrobiology, Department of Biology, Aarhus University, Aarhus, Denmark. ${ }^{2}$ Center for Applied Geosciences, University of Tübingen, Tübingen, Germany. ${ }^{3}$ Department of Geological Sciences and Environmental Studies, Binghamton University, New York, USA. ${ }^{4}$ Present address: GEOMAR, Helmholtz Centre for Ocean Research Kiel, Kiel, Germany. ${ }^{5}$ Present address: Bigelow Laboratory for Ocean Sciences, Maine, USA. ${ }^{6}$ Present address: School of Earth Sciences, University of Bristol, Wills Memorial Building, Bristol, UK. ${ }^{凶}$ email: klaufer@geomar.de
} 
T he Arctic regions are warming 2-3 times faster than the global average ${ }^{1}$. Arctic glaciated fjord ecosystems, which are hotspots of carbon cycling and burial ${ }^{2,3}$, are predicted to be extremely sensitive to this warming 4 . Iron is an essential nutrient for phytoplankton and limits primary productivity across $30-40 \%$ of the global ocean area ${ }^{5}$. The Arctic Ocean is generally not considered to be iron-limited ${ }^{6}$. However, in the proximal North Atlantic Ocean, as well as the Nansen Basin and eastern Fram Strait of the Arctic Ocean, recent research indicates that seasonal and/or regional iron-limitation could exist and be exacerbated with climate change $\mathrm{e}^{7-9}$.

Glaciers and ice sheets are a primary iron source to the oceans, along with rivers, hydrothermal vents, and aeolian dust ${ }^{10-13}$. The majority of glacially derived iron is in the particulate form or will rapidly become particulate once in contact with oxic and saline fjord water due to oxidation and flocculation, resulting in up to $95 \%$ of glacially sourced iron settling to fjord sediments after entering the marine environment ${ }^{14-16}$. It was found that irondelivery by glaciers is dependent on bedrock geology and that benthic iron cycling is active in these sediments, which could play a significant role in the production of bioavailable iron ${ }^{17,18}$. However, the amount and physical-chemical characteristics of glacial iron, as well as its fate once delivered to the fjords, still remain poorly constrained ${ }^{10,19}$. The physical-chemical characteristics that determine if iron minerals will be available for biological processes are related to the speciation, particle size, surface area, and crystallinity ${ }^{20,21}$. Neutral-buffered ascorbate selectively extracts poorly crystalline, highly labile $\mathrm{Fe}(\mathrm{III})$ and surface-bound $\mathrm{Fe}(\mathrm{II})^{22}$, which are potentially bioavailable for phytoplankton $15,23,24$ and favorable for microbial reduction ${ }^{25,26}$. Surface-bound $\mathrm{Fe}(\mathrm{II})$ has been found to be a minor fraction of iron in Svalbard fjord sediments ${ }^{27}$. Therefore, we assume that the most neutral-buffered ascorbate-extractable iron (FeA) is $\mathrm{Fe}(\mathrm{III})$. While previous studies have focused on the delivery of iron to marine ecosystems by icebergs ${ }^{28,29}$ and proglacial meltwater ${ }^{13,30}$, these sources contain low amounts of FeA $(0.75-26 \mu \mathrm{mol}$ per gram dry weight $\left.\left(\mathrm{g} \mathrm{dw}^{-1}\right)\right)^{13,28-30}$, compared to what has been reported for fjord sediments $\left(9.5-176 \mu \mathrm{mol} \mathrm{g} \mathrm{dw}^{-1}\right)^{26,31}$. It is not well understood how benthic processes in fjord sediments are impacted by the input of glacial iron and, conversely, how benthic processes impact the physical and chemical characteristics of glacially derived iron. Determining what happens after glacially derived iron settles to fjord sediments is crucial to evaluate if these sediments function as a net source or sink of potentially bioavailable iron.

Iron is not simply buried in marine sediments after deposition. An interplay of biotic and abiotic reactions drive the benthic biogeochemical iron cycle and transform the speciation, mineralogy, and physical-chemical characteristics of iron ${ }^{32,33}$. The reduction of $\mathrm{Fe}$ (III) in sediments is catalyzed by abiotic redox reactions with sulfide or organic matter, and by biotic redox reactions mediated by microorganisms ${ }^{33}$. Microorganisms preferentially reduce labile, poorly crystalline $\mathrm{Fe}(\mathrm{III})$ minerals during organic carbon mineralization due to the high energy yield and relatively large surface area. However, over longer timescales microorganisms can also reduce highly crystalline $\mathrm{Fe}(\mathrm{III})$ minerals, such as hematite or iron in silicates ${ }^{25,34}$. Fe(II) is oxidized by abiotic reactions with oxygen, $\mathrm{Mn}(\mathrm{IV})$-oxides or reactive nitrogen species, and by biotic reactions mediated by microorganisms. Microorganisms are thought to preferably oxidize dissolved $\mathrm{Fe}(\mathrm{II})$ with oxygen or nitrate as electron acceptors or coupled to anoxygenic photosynthesis ${ }^{33}$, while producing highly labile, poorly crystalline, biogenic Fe(III) minerals ${ }^{35}$. However, solid-phase $\mathrm{Fe}(\mathrm{II})$ in silicate or sulfide minerals is also available for oxidation by microorganisms ${ }^{36}$, and abundant in glacial systems ${ }^{20,37}$. The benthic iron cycle is connected to many other element cycles $^{33}$. Thus, changes to the iron cycle create a cascade of impacts for example on the availability of phosphate and other nutrients and, most importantly, on the cycling and burial of carbon.

With ongoing warming, glacier termini are retreating from the sea onto land, which will lead to changes in the processing and export of glacially derived material ${ }^{38}$. The glacial retreat also causes changes in water circulation and primary productivity in the fjord ecosystem ${ }^{39-41}$. Arctic fjords are significant sinks of carbon $^{2,3}$. It remains unknown how glacial retreat onto land will impact the processing of glacially sourced iron in fjord sediments and affect its speciation, transport and bioavailability. If iron cycling in fjord sediments is sensitive to glacial retreat, then this could change iron supply to fjord waters, and thereby have profound effects on fjord primary productivity and carbon cycling.

Here we show the effects of glacially derived iron on benthic processes in fjord sediments. Specifically, we quantify how benthic processes change the characteristics of glacially derived iron, and discuss the potential impacts of benthic processes on iron bioavailability and export to the water column. We quantified the amount of potentially bioavailable, ascorbate-extractable iron (FeA) and microbially reducible iron $(\mathrm{FeM})^{26,42,43}$ using time-course extractions. We chose the time-course extractions because the dissolution kinetics of the iron during the extractions provide valuable data on the amount $\left(\mathrm{M}_{(0)}\right)$, reducibility (v/a), lability (initial rate, taking into account the amount and reducibility), and composition $(1+1 / \mathrm{v}$, impacted by the mineralogy, particle size and crystallinity, where a value close to 1 shows the uniform composition and a value $>1$ shows a more complex composition) of the extracted iron pool (Table 1). While classically all $\mathrm{FeA}$ is defined as labile, with the lability parameter we can quantify how labile the FeA pool is, which allows for a more detailed comparison. Moreover, we used sequential end-point $\mathrm{HCl}$ extractions, which preserve the redox speciation of the extracted $\mathrm{Fe}$, to measure the poorly crystalline $(0.5 \mathrm{M} \mathrm{HCl})$ and crystalline $(6 \mathrm{M} \mathrm{HCl})$ sedimentary iron pool, together yielding the total $\mathrm{HCl}$-extractable iron (Table 1). Finally, we used ${ }^{57} \mathrm{Fe}$ Mössbauer spectroscopy for the identification of iron-mineralogy within the glacial source and sediment samples. We find that the amount and reducibility of FeA and FeM from glacial sources (icebergs, proglacial rivers, proglacial plumes) is relatively low, while the amount and reducibility of FeA and FeM in the fjord sediments increases with distance from the fjord head. This pattern of increasing FeA and FeM holds across three Svalbard fjords with differing glacial regimes and catchment geology. We conclude that fjord sediments are a bioreactor for authigenic labile iron production and that this process is enhanced from the fjord head to mouth. Moreover, fjord sediments represent a potentially important, but yet overlooked, source of potentially bioavailable iron to the overlying water column; however, the iron cycle is sensitive to glacial retreat which may reduce the fjord sediments role in supplying potentially bioavailable iron to the water column.

\section{Results and discussion}

Composition of iron in glacial sources. Particulate material collected from a variety of glacial sources in Kongsfjorden had a high total iron content $(320-1400 \mu \mathrm{mol}$ total $\mathrm{HCl}$ extractable Fe g $\mathrm{dw}^{-1}$, Supplementary Table 1, Fig. 1), which is within the range previously reported for glacial sources worldwide (500-1600 $\left.\mu \mathrm{mol} \mathrm{g} \mathrm{dw}^{-1}\right)^{11}$. However, iron minerals in these glacial sources contained relatively low amounts of FeA (Table 1), with $30.9 \pm$ 4.6, 28.1 \pm 12.9 , and $8.1 \pm 6.1 \mu \mathrm{mol} \mathrm{g} \mathrm{dw}^{-1}$ in particulate material from the proglacial plumes, meltwater rivers, and iceberg 
Table 1 Description of the abbreviations and parameters of the applied Fe-extrication methods.

\begin{tabular}{|c|c|c|c|}
\hline $\begin{array}{l}\text { Ascorbate Fe reduction time-course } \\
\text { extractions }\end{array}$ & $\begin{array}{l}\text { Ascorbate extractable } \\
\text { iron (FeA) }\end{array}$ & $\begin{array}{l}\mathrm{M}_{(0)} \\
1+1 / \mathrm{v} \\
\mathrm{v} / \mathrm{a} \\
\text { Initial rate }\end{array}$ & $\begin{array}{l}\text { Amount of } \mathrm{FeA} \\
\text { Composition } \mathrm{FeA} \\
\text { Reducibility of FeA } \\
\text { Lability of ascorbate extractable iron }\end{array}$ \\
\hline $\begin{array}{l}\text { Microbial Fe reduction time-course } \\
\text { extractions }\end{array}$ & $\begin{array}{l}\text { Microbially extractable } \\
\text { iron (FeM) }\end{array}$ & $\begin{array}{l}\mathrm{M}_{(0)} \\
1+1 / \mathrm{v} \\
\mathrm{v} / \mathrm{a} \\
\text { Initial rate }\end{array}$ & $\begin{array}{l}\text { Amount of microbially extractable iron } \\
\text { Composition of microbially } \\
\text { extractable iron } \\
\text { Reducibility of microbially } \\
\text { extractable iron } \\
\text { Lability of microbially extractable iron }\end{array}$ \\
\hline Sequential $\mathrm{HCl}$ extractions & $\begin{array}{l}\mathrm{HCl} \text {-extractable iron } \\
(\mathrm{FeHCl})\end{array}$ & $\begin{array}{l}0.5 \mathrm{M} \mathrm{HCl} \mathrm{Fe}(\mathrm{II}) \\
0.5 \mathrm{M} \mathrm{HCl} \mathrm{Fe}(\mathrm{III}) \\
0.5 \mathrm{M} \mathrm{HCl} \mathrm{Fe} \text { (total) } \\
6 \mathrm{M} \mathrm{HCl} \mathrm{Fe}(\mathrm{II}) \\
6 \mathrm{M} \mathrm{HCl} \mathrm{Fe}(\mathrm{III}) \\
6 \mathrm{M} \mathrm{HCl} \mathrm{Fe} \text { (total) } \\
\text { Total FeHCl }\end{array}$ & \\
\hline
\end{tabular}

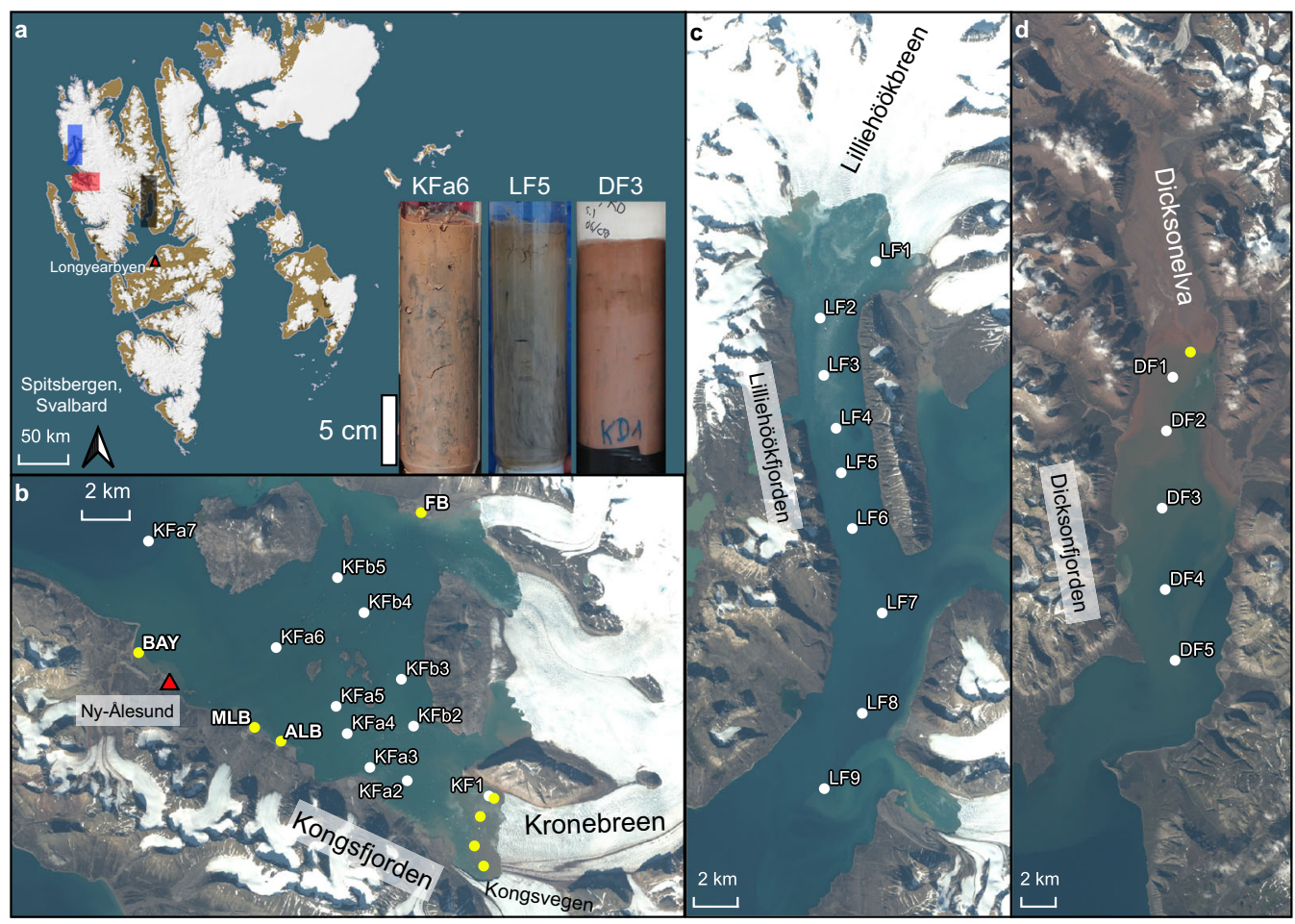

Fig. 1 Map of sampling stations. a Overview map of Svalbard, with the three investigated fjords indicated by colored rectangles, and examples of a sediment core from each fjord (Kongsfjorden = red, core KFa6; Lilliehöökfjorden = blue, core LF5; Dicksonfjorden = gray, core DF3). b-d Maps of sampling stations in the individual fjords; b Kongsfjorden, c Lilliehöökfjorden, d Dicksonfjorden. White dots represent sediment sampling stations. Yellow dots represent glacial source sampling stations; BAY Bayelva river, MLB Midre Lovenbreen, ALB Austre Lovenbreen, FB Ferringbreen. The yellow dots without labels indicate plume and iceberg samples. Red triangles show the location of NyAlesund and Longyearbyen for orientation. 10-m satellite imagery from Sentinel-2 taken on 2 August 2017.

samples, respectively ${ }^{26}$ (Fig. 2a). Fe mineralogical composition detected by ${ }^{57} \mathrm{Fe}$ Mössbauer spectroscopy also showed that a large proportion of iron in the glacial source material is highly crystalline and not extractable by ascorbate. Iron in a Kongsfjorden plume sample had a relative abundance of $17.8 \pm 1.6 \%$ hematite, whereas material from a Kongsfjorden iceberg contained about twice as much hematite, accounting for $41.3 \pm 1.9 \%$ of the iron pool (Supplementary Fig. 1, Supplementary Table 2). These data corroborate results of Raiswell and coworkers ${ }^{15}$, who showed that labile iron produced by chemical and biological weathering in subglacial systems gets slowly converted into less labile phases such as goethite or hematite in glacial ice ${ }^{15}$. Alternatively, this could be a function of the hematite content of the Devonian-age red sandstone underlying the glaciers at the head of 


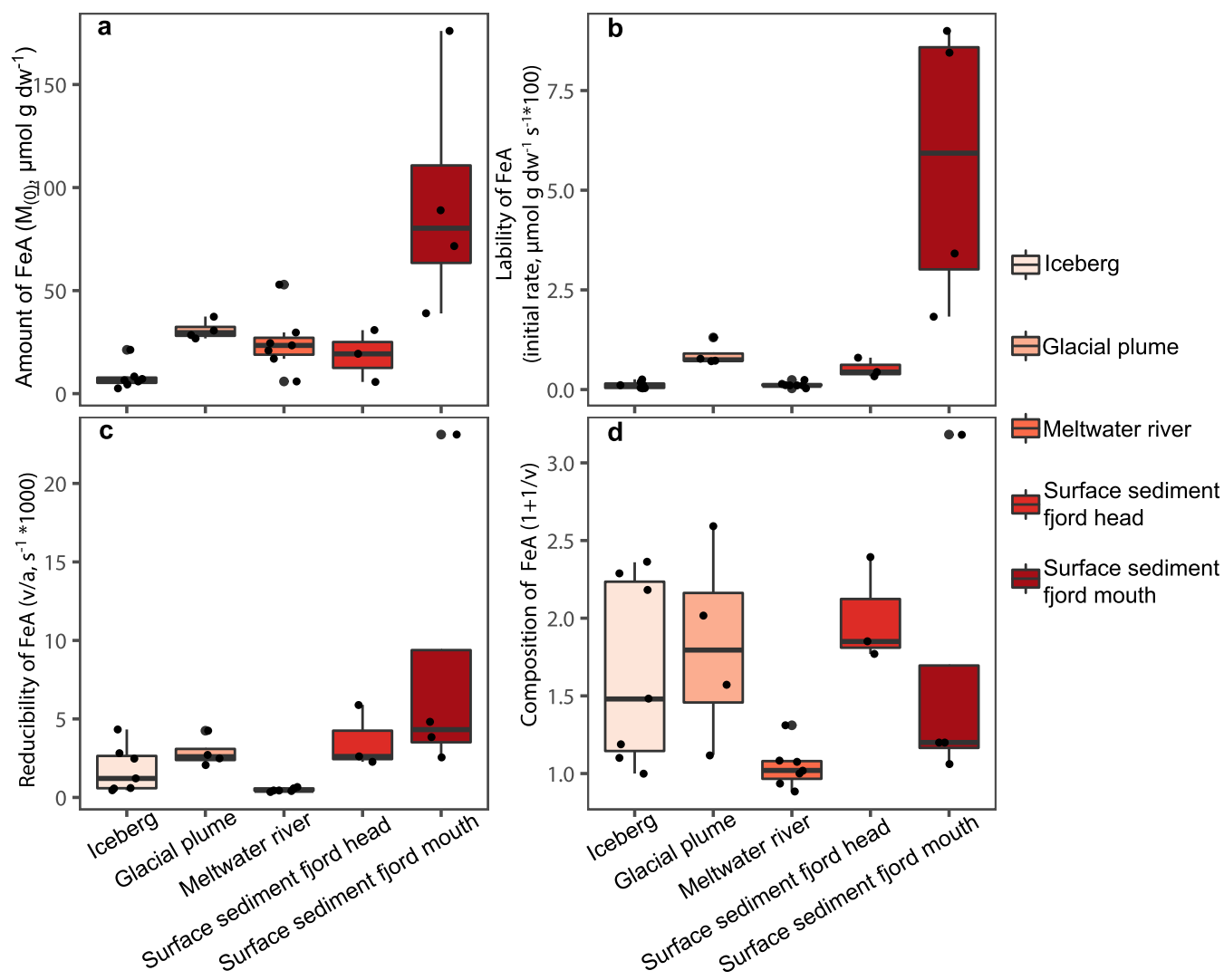

Fig. 2 Amount and characteristics of ascorbate-extractable Fe (FeA) from the glacial source material and fjord surface sediment. All data points are shown as black dots. The red boxes show the interquartile range and the thick horizontal line in the boxes shows the median. The vertical line at the top and the bottom of the boxes shows the maximum and the minimum, defined as $1.5 \times$ interquartile range. a Amount of FeA, $\mathbf{b}$ lability of FeA, $\mathbf{c}$ reducibility of FeA, and $\mathbf{d}$ composition of FeA. Surface sediment values are from 0 to $1 \mathrm{~cm}$ sediment depth.

Kongsfjorden ${ }^{44}$, which is being crushed and directly incorporated into glacial ice. Glacial sources contain relatively low amounts of FeA, such that only a small fraction $(0.6-12 \%$, average $3.3 \%)$ of glacially derived iron is potentially bioavailable for phytoplankton ${ }^{23}$. These data are in agreement with previous results showing a high total iron content, but a low amount of FeA in glacial sources of Kongsfjorden ${ }^{15,29}$. The amount of FeM was about two times higher than FeA (Supplementary Table 1), consistent with what has been previously found ${ }^{26}$ and attributed to the large surface area of these glacial sediments being favorable for microbial reduction, differences in the mineral phases available to biotic and abiotic processes, and differences in mechanisms of biotic and abiotic iron reduction ${ }^{26}$. Still, FeM, representing the fraction of iron that is available for a microbial reduction under ideal, non-limiting laboratory conditions ${ }^{26}$, was a small fraction of the total iron in these samples $(1.1-30 \%$, average 9.4\%).

Samples from the same type of glacial source in Kongsfjorden generally contained a similar amount of FeA, but there were some exceptions (Fig. 2a). The iceberg and meltwater plume samples from Kongsvegen contained a higher (3.6 and 1.3-fold, respectively) amount of $\mathrm{FeA}$ compared to the samples from Kronebreen (Supplementary Table 1). The differences in FeA content found in Kongsvegen and Kronebreen samples are likely to be caused by differences in bedrock geology. Kongsvegen overrides Carboniferous-Permian age limestones and dolostones, whereas Kronebreen overrides iron-rich, Devonian age red sandstones ${ }^{44}$, resulting in strikingly different colors of the sediment (Supplementary Fig. 2). It is also possible that these differences could be a function of differential processing of material within the two glacial systems before delivery to the fjord. Samples from Austre Lovenbreen, which were collected in consecutive years, also contained variable amounts of FeA (Supplementary Table 1). However, the parameters determined in FeA extractions (lability, reducibility, and composition) were similar. This indicates that the pool of FeA from the Austre Lovenbreen catchment in both years was similar, but more dilute in one year compared to the other. In general, we found that samples from the same type of glacial source contained FeA with similar characteristics, as can also be seen from the similar shape of the dissolution curves (Supplementary Fig. 3).

The composition of FeA describes the diversity $(1+1 / \mathrm{v}>1)$ or uniformity $(1+1 / \mathrm{v}$ close to 1$)$ of the mixture of $\mathrm{Fe}$ minerals contained within the sediment in terms of mineralogy, particle size, and/or crystallinity. The composition of FeA was highest for the particles from the proglacial plume at the head of Kongsfjorden and the lowest for the meltwater rivers in Kongsfjorden $(1+1 / \mathrm{v}$ of $1.83 \pm 0.6$ and of $0.99 \pm 0.1$, respectively, Fig. 2d). These results indicate that glacial iron transported by proglacial rivers gets sorted or chemically or physically modified, such that a uniform type of iron mineral is supplied by these rivers, whereas proglacial plumes emanating from beneath the marine-terminating glacier deliver a more diverse pool of FeA. Kongsfjorden glacial plume contained the highest FeA lability of glacial source material, which was 8 -fold higher compared to the average of the icebergs $\left(8.8 \times 10^{-3} \pm 2.9 \times 10^{-3} \mu \mathrm{mol} \mathrm{g} \mathrm{dw}^{-1} \mathrm{~s}^{-1}\right.$, Fig. 2b). This highlights that glacial meltwater emanating in front of Kronebreen, contains FeA that was produced by subglacial processes that promote the production of potentially bioavailable $\mathrm{Fe}$, such as biogeochemical weathering ${ }^{15}$. Despite this, the 

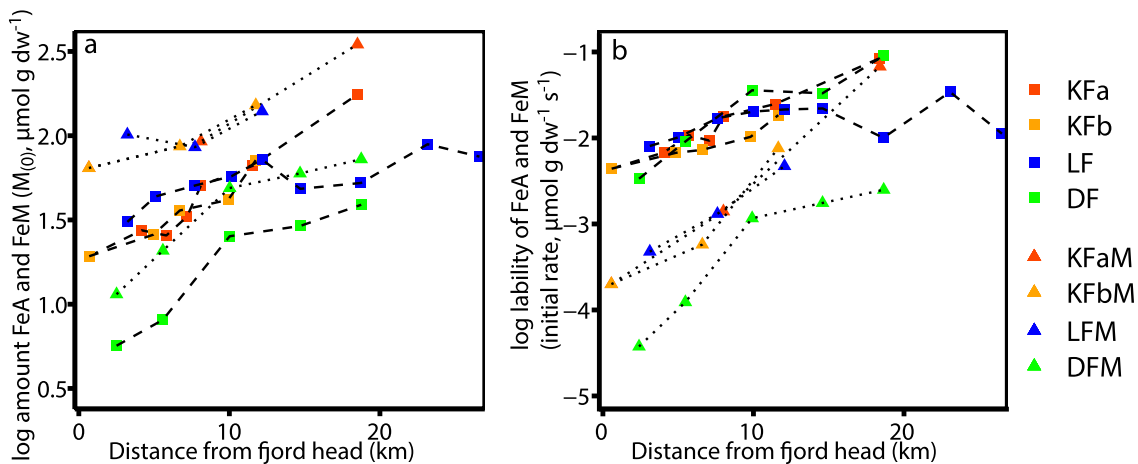

Fig. 3 Amount $\left(M_{(0)}\right)$ and lability (initial rate) of ascorbate extractable Fe (FeA) and microbially extractable Fe (FeM) versus distance from the fjord head. a, b Amount $\left(M_{(0)}\right)$ and reducibility (initial rate), respectively, of FeA (squares) and FeM (triangles) in surface sediment.

Kongsfjorden glacial source sample with the highest lability of $\mathrm{FeA}$ is ten times lower than the highest reported values of Kongsfjorden sediment ${ }^{26}$ (Fig. 2).

Particulates collected in the plume of the meltwater river at the head of Dicksonfjorden (Dicksonelva, Fig. 1) had only a fifth of the amount of FeA that was found in the plumes of Kongsfjorden meltwater rivers. The amount of FeA in Dicksonelva particulates $\left(5.95 \mu \mathrm{mol} \mathrm{g} \mathrm{dw}^{-1}\right.$, Fig. 2a) is similar to the average of the Kongsfjorden iceberg samples. Also, the lability and reducibility of FeA of Dicksonelva particulates were most similar to the lowest values that we found for the icebergs in Kongsfjorden. The lability of FeA in Dicksonelva particulates was only one fourth of what we measured for Kongsfjorden river particulates and 25-times lower compared to the proglacial plume in Kongsfjorden. The composition of FeA $(1+1 / \mathrm{v}$ of 1.31) was more complex than the meltwater rivers in Kongsfjorden (Supplementary Table 1). Dicksonelva is different from the meltwater rivers in Kongsfjorden as it enters the fjord in a large delta with an intertidal mudflat ${ }^{45}$, which seems to affect the transport and/or transformation of FeA. Previous studies have concluded that sediment transport in meltwater rivers will transform minerals into more labile phases due to increased weathering ${ }^{27}$. We hypothesize that, as the amount and lability of FeA were most similar to iceberg samples from Kongsfjorden, and much lower than in all other measured meltwater rivers, this does not seem to hold true for Dicksonelva.

Our results show that only a limited fraction of the total iron delivered by glaciers is potentially bioavailable iron, independent of the glacial regime or source type. We also find that the characteristics (reducibility, lability, and composition) of iron delivered by different glacier and glacial source types, differ. Based on these findings we conclude that glacial retreat and shrinkage could lead to changes in the amount and characteristics of iron that is delivered to fjords.

Spatial distribution of $\mathrm{Fe}$ in Kongsfjorden sediment. The amount and lability of FeA at the fjord head (KF1; Fig. 1) were the lowest of all surface sediment samples within the Kongsfjorden transects (Fig. 3). FeA at KF1 was similar to the mean of Kongsfjorden glacial sources (Figs. 2 and 3) and implies there is little processing of iron at the head of the fjord, likely because the sedimentation rates are very high close to glacial meltwater inputs ${ }^{14}$. The amount and lability of FeA in surface sediment in Kongsfjorden increased by ninefold and 19-fold, respectively, at the station furthest away from the fjord head compared to the station closest to the fjord head in the southern $(\mathrm{KFa})$ transect (Fig. 3). A similar increase in FeA amount and lability over distance was found in the northern $(\mathrm{KFb})$ transect of Kongsfjorden (Fig. 3). These increases are exponential as seen from the linear increase in the semi-log-plot (Fig. 3) and an $R^{2}$ of 0.96 and 0.94 for the $\mathrm{KFa}$ and $\mathrm{KFb}$ transects, respectively, when fitting an exponential model through the data (Supplementary Table 3). FeM showed even more pronounced differences in the amount and lability at the surface of station $\mathrm{KFa} 7$ and $\mathrm{KFb} 5$ compared to all the sources (Fig. 3). These increases in FeA and FeM are either produced by preferential transport of the smallest and most labile particles, a reworking of particles during transport in the water column, or by the processing of the iron upon sedimentation, producing authigenic FeA and FeM.

The composition of $\mathrm{FeA}$ in the transects became more complex over the first few $\mathrm{km}$ distance (from a $1+1 / \mathrm{v}$ of 1.85 at KF1 to 2.18 and 2.06 at $\mathrm{KFa} 4$ and $\mathrm{KFb} 3$, respectively), likely due to the glacial sources containing $\mathrm{FeA}$ with varying composition and authigenic production of $\mathrm{FeA}$ within the sediment. At stations with a greater distance to the fjord head, the composition of $\mathrm{FeA}$ became more homogeneous again, reaching values as low as 1.20 at $\mathrm{KFa} 7$ and $\mathrm{KFb} 5$, indicating the presence of a more uniform pool of highly labile iron (Fig. 2). These changes imply that significant processing of iron occurred after sedimentation at stations further away from the fjord head, likely through microbial dissimilatory iron reduction or interactions with sulfide $^{27,31}$. Our data show that a homogenous pool of highly labile and potentially bioavailable $\mathrm{FeA}$ is accumulating in the surface sediments of Kongsfjorden as the distance from the glacial source increases (Fig. 2 and S4).

These results are consistent with ${ }^{57} \mathrm{Fe}$ Mössbauer spectroscopy, which showed that the content of labile and crystalline iron minerals in KF1 sediment was similar to the Kronebreen plume (e.g., $21.1 \pm 1.3$ and $17.8 \pm 1.6 \%$ of hematite was found in KF1 sediment and the Krobebreen plume, respectively). The mineral composition of $\mathrm{KFa} 7$ sediment was different from KF1 and the Kronebreen plume, with lower proportions of crystalline minerals (e.g., only $10.3 \pm 2.1 \%$ hematite, Supplementary Fig. 1 , Supplementary Table 2). This distribution of iron minerals with different crystallinities could be caused by the transport of the finest and most labile particles to the more distant stations, which would also explain the higher lability of FeA. However, the lability of $\mathrm{FeA}$ in $\mathrm{KFa} 7$ surface sediment is higher than any value measured in the proglacial plume, and also notably higher (8.6fold) than the average of all glacial sources (Fig. 2b). Taken together, these data indicate that the abundant iron mineral species were dominated by less crystalline, more labile iron phases further from the head of the fjord and that they might be authigenic.

Catchment geology impact on Fe cycling. An increase in the amount of FeA over distance from the fjord head was also found in Lilliehöökfjorden, reaching a maximum of $89 \mu \mathrm{mol} \mathrm{g} \mathrm{dw}^{-1}$ at 
LF8, which is a 3.9 -fold increase within the $23 \mathrm{~km}$ transect (Fig. 3). The lability of FeA also increased 4.3-fold in our Lilliehöökfjorden transect (Fig. 3). FeM shows the same increasing trend in amount and reducibility (Fig. 3). The catchment geology of Lilliehöökfjorden is dominated by metamorphic rocks such as marble, mica-schist, and minor amounts of quartzite of Middle Proterozoic age, while Kongsfjorden is dominated by Devonian red sandstone as well as Carboniferous-Permian age dolostone and limestone ${ }^{44}$. Still, the same patterns of an increasing amount of lability of FeA were found in two fjords, despite the diversity of bedrock types supplying material to each fjord. This pattern of increasing labile iron content with distance from the fjord head was also observed in two fjords in southwestern Svalbard (determined by hydroxylamine-hydrochloride extractions) ${ }^{27}$. Van Mijenfjorden and Van Kuelenfjorden in southern Spitsbergen, Svalbard drain even more diverse bedrock assemblages and reinforce the widespread nature of these patterns in fjord sediments. The increases we observe in Kongsfjorden are statistically significant over the entire length of the transects (Supplementary Table 3). However, the increase of FeA within Lilliehöökfjorden is interrupted where Möllerfjorden and Lilliehöökfjorden merge (between LF6 and LF7; Figs. 1 and 3), likely due to nearby glaciers from Möllerfjorden supplying less labile iron to the sediments. The increases in the amount and lability of FeA are significant if only the data until LF5 are included in the analysis. If we consider the entire transect, including stations from LF6 and outward, which are impacted by Möllerfjorden, the amount of FeA over distance has low significance and the increase in the lability over distance has no significance. (Supplementary Table 3). These data show the sensitivity of fjord sediments to nearby glacial meltwater inputs.

The composition of the Lilliehöökfjorden FeA pool develops in a manner similar to the two transects in Kongsfjorden, where a diverse pool of $\mathrm{FeA}$ becomes progressively more uniform in composition with distance from the fjord head (Supplementary Fig. 4). No hematite could be identified by ${ }^{57} \mathrm{Fe}$ Mössbauer spectroscopy in Lilliehöökfjorden samples and the iron mineral composition was different from Kongsfjorden as expected from the different bedrock assemblage and sediment color (Fig. 1, Supplementary Fig. 5, and Supplementary Table 2). Collected spectra were similar for LF1 and LF5, with a higher proportion of $\mathrm{Fe}$ (III) towards the fjord mouth (LF5) compared to the fjord head (LF1). This increase in the relative abundance of Fe(III) detected by ${ }^{57} \mathrm{Fe}$ Mössbauer spectroscopy supports the trend of increasing authigenic $\mathrm{Fe}$ (III) minerals in sediment nearer the fjord mouth as also determined with Fe extractions. Consequently, the oxidation of glacially derived $\mathrm{Fe}(\mathrm{II})$ to $\mathrm{Fe}(\mathrm{III})$, by biotic or abiotic processes $^{33}$, appears to be important for the production of FeA in Lilliehöökfjorden. In conclusion, the increases of FeA and FeM in fjord sediments toward the fjord mouth, irrespective of catchment geology, reveals a gradual transformation of glacially derived $\mathrm{Fe}$ into more labile phases. We predict this to be a widespread process in glaciated fjords.

FeA and FeM production through benthic cycling. Sedimentation gradients in Arctic fjords caused by particle transport in freshwater lenses provide one possible explanation for the observed gradients in FeA and FeM by carrying the finest and most labile particles furthest ${ }^{14}$. However, we did not find evidence for long-distance transport of the finest and most labile glacial iron in the observed gradients. Over $95 \%$ of the grain size distributions from surface sediment samples recovered along the transects are characterized by silt and clay $(<63 \mu \mathrm{m}$ or $4 \phi)$ (Supplementary Fig. 6). We found no systematic relationship between the percent of fine-grained material and the distance

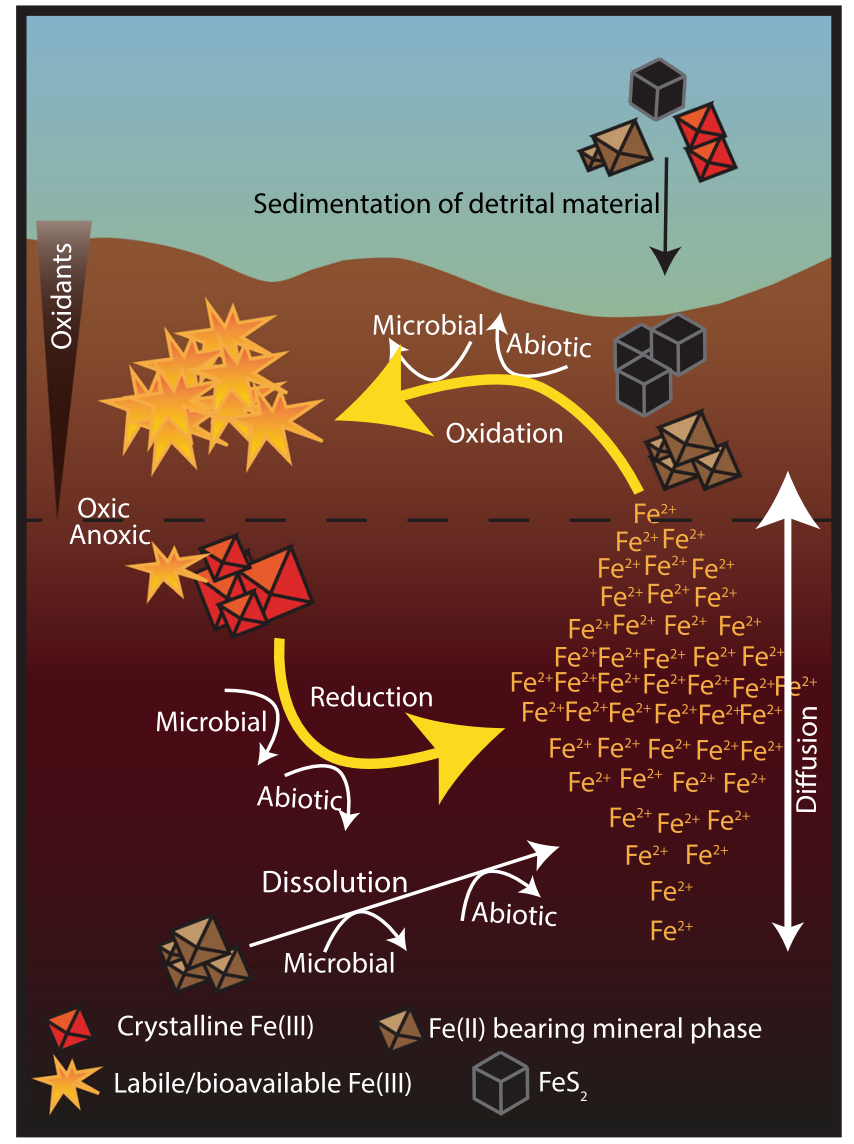

Fig. 4 Schematic figure of benthic iron cycling. Illustration of the production of ascorbate-extractable $\mathrm{Fe}(\mathrm{FeA})$ and microbially extractable $\mathrm{Fe}$ (FeM), which is labile and potentially bioavailable Fe, at the oxic-anoxic interface in fjord sediments. These sediments are unique to other marine sediments, as glacial input provides huge quantities of $\mathrm{Fe}$ (III) and Fe(II) bearing minerals to the sediment surface.

from the fjord head (Supplementary Fig. 6, further information see SI). There is a small decrease in grain size over the first $8 \mathrm{~km}$ of the transect, but there is no change after that, while FeA and FeM still continue to increase beyond this point (Fig. 3). Fe cycling within Fe-organic matter aggregates suspended in the water column could increase iron lability during transport. However, we argue that the time to deposition is relatively short in these shallow fjords $(<350 \mathrm{~m})$, compared to the deep, open ocean where $\mathrm{Fe}$-organic matter aggregate studies have been previously conducted ${ }^{46,47}$. Compared to the time available for cycling in the sediments afterwards, the impact of cycling in the water column is likely minor. We conclude that the increase of $\mathrm{FeA}$ and FeM over distance cannot be explained as a function of the preferential transport of small and reactive particles or transformation during transport through the water column.

We propose that the main driving force for the higher FeA and FeM content and lability of fjord sediments is benthic cycling through an interplay of abiotic and biotic processes ${ }^{33}$ (Fig. 4). These processes produce authigenic, poorly crystalline, highly labile, and easily reducible iron at the oxic sediment surface (Fig. 5), underlying oxic bottom waters, through abiotic or microbially mediated oxidation of $\mathrm{dFe}(\mathrm{II})^{33}$. Steep concentration gradients with sediment depth, driving a flux of $\mathrm{dFe}$ (II) into the oxic sediment layers, were found at all stations in Kongsfjorden and Lilliehöökfjorden (Supplementary Fig. 7). The source of Fe (II) is a combination of: (i) reductive dissolution of Fe(III) from $\mathrm{Fe}$ (III) (oxyhydr)oxides, (ii) pyrite, originating from the bedrock 


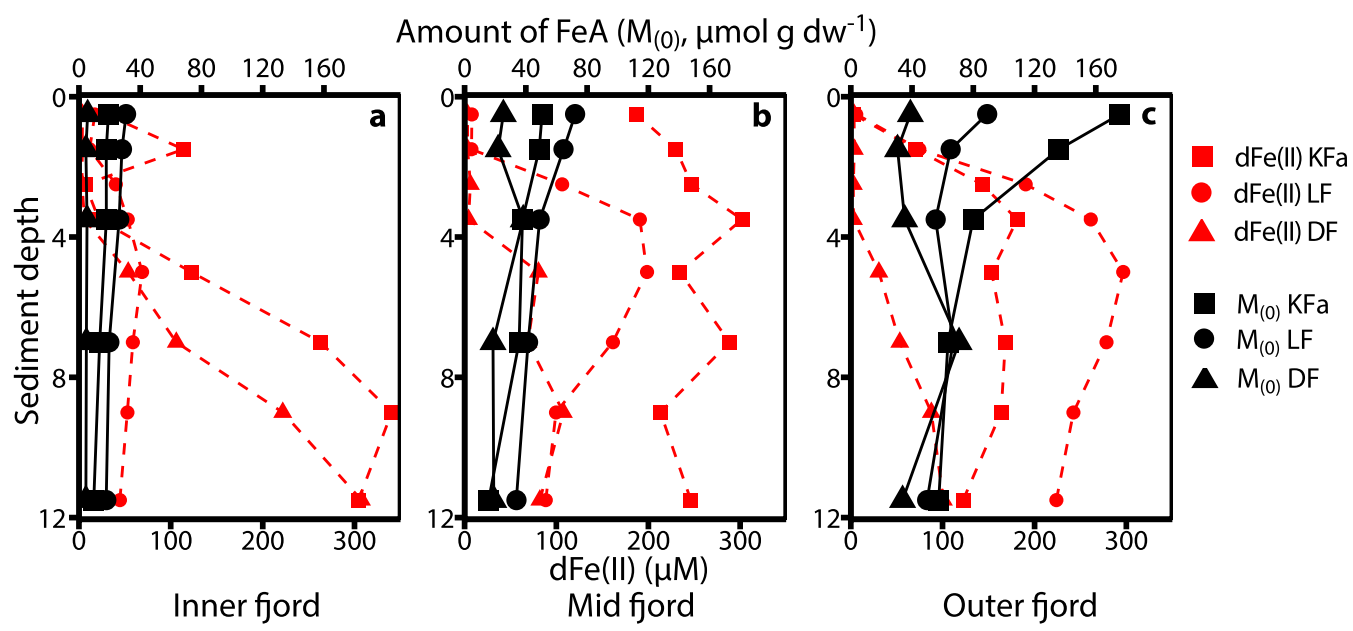

Fig. 5 Concentrations of ascorbate-extractable Fe (FeA) and dissolved iron over sediment depth at three stations within the transects. The three frames show the amount of $\mathrm{FeA}$ and the concentration of dissolved iron (dFe(II)) in the pore water versus sediment depth at a stations closest to the fjord head (Kongsfjorden $(K F a)=K F a 1$, Lilliehöökfjorden $(L F)=L F 1$, Dicksonfjorden $(D F)=D F 1)$; b mid-fjord stations $(K F a=K F a 5, L F=L F 5, D F=D F 3)$; and $\mathbf{c}$ : stations closest to the fjord mouth (KFa $=K F a 7, L F=L F 8, D F=D F 5)$.

beneath the glacier ${ }^{18}$, and (iii) dissolution of other $\mathrm{Fe}(\mathrm{II})$-bearing minerals such as $\mathrm{Fe}(\mathrm{II})$-carbonates or primary silicates through microbial or abiotic weathering processes ${ }^{48}$ (Fig. 4). Over timescales of years to decades these processes are likely to access the fractions of the glacially derived Fe, which initially are not extractable by ascorbate or microorganisms. Which of the possible $\mathrm{Fe}(\mathrm{II})$ sources is most important in the different fjord sediments is a function of the catchment geology, geochemical conditions, and microbial activity. Regardless of the source of Fe (II), we propose that $\mathrm{Fe}(\mathrm{II})$-oxidation at the sediment surface produces authigenic $\mathrm{Fe}(\mathrm{III})$ minerals.

We observe a strong gradient in $\mathrm{FeA}$ and $\mathrm{FeM}$ from fjord head to mouth, indicating that the process that produces $\mathrm{FeA}$ and $\mathrm{FeM}$ at the sediment surface gets stronger and/or decreasing sedimentation rates provide more time for these processes with increasing distance from the glacial source. In glaciated fjords, steep gradients in hydrology, biology, and geochemistry exist due to inputs of glacial material at the fjord head and the marine influence at the fjord mouth ${ }^{2,49}$. At the fjord head, high sedimentation rates of detrital material and low primary productivity within a thin photic zone $\mathrm{e}^{14,50}$, lead to sediment with low TOC content, caused by low primary productivity and the dilution effect of lithogenic material. We found organic carbon with a high C:N ratio of up to 70 in sediment close to the glacial source in Kongsfjorden (Fig. 6), originating from the terrestrial input of petrogenic organic carbon ${ }^{51}$. Petrogenic organic carbon is more resistant to microbial degradation compared to fresh marine organic carbon ${ }^{52}$. Terrestrial organic carbon usually has $\mathrm{C}: \mathrm{N}$ values $>20$, while fresh marine organic matter usually has lower $\mathrm{C}: \mathrm{N}$ values around $6-9^{3}$, and is more readily available to microbial degradation compared to terrestrial material ${ }^{52}$. Towards the fjord mouth TOC contents gradually increased, while C:N ratios decreased and approached a more marine-like signature (Fig. 6). Towards the mouth there is higher primary productivity and greater input from Atlantic water, leading to more marine organic matter settling to the sediment ${ }^{50,51}$. Similar trends of increasing TOC and decreasing $\mathrm{C}: \mathrm{N}$ with distance from the fjord head were reported previously for Svalbard fjords ${ }^{2,27}$ and C:N values of up to 50 have also been reported for Greenlandic fjords $s^{53}$. We conclude that sediments close to glaciers can sustain only moderate activity of microbial Fe (III)- or sulfate-reduction due to the low amount and refractory characteristics of the organic carbon, which is supported by the low sulfate reduction rates (Fig. 6). Further from the glacier, the sedimentation rate of inorganic detrital material decreases and organic carbon export to the sediments increases, producing sediment with a higher TOC content and lower $\mathrm{C}: \mathrm{N}^{49}$. The higher amount of organic carbon with a lower $\mathrm{C}: \mathrm{N}$ ratio, as well as lower sedimentation rates, altogether create more favorable conditions for Fe-cycling at the sediment surface further away from the glacial source, as the organic carbon can support higher rates of microbial $\mathrm{Fe}(\mathrm{III})$ reduction and sulfate reduction (Fig. 6) ${ }^{31}$, both leading to the production of $\mathrm{dFe}(\mathrm{II})$.

Based on our TOC and C:N results, we expected SRR to increase concurrently with the increase in TOC and the decrease in C:N. However, depth-integrated rates of SRR show no consistent increase with distance from the fjord head (Fig. 6). SRR do not increase as expected along with the TOC and C:N gradients, which is likely caused by the concurrent increase in FeA and FeM along the transect, enabling Fe-reducers to compete favorably with sulfate-reducers (for a more detailed discussion of SRR in relation to TOC and C:N, see SI). In addition to the increased activity of benthic iron cycling, the lower sedimentation rates in the outer part of fjords ${ }^{49}$ lead to a more abundant and active benthic fauna ${ }^{54}$, which further intensifies benthic cycling 55 . Lower sedimentation rates also lead to increased time for iron to be repeatedly cycled before it gets buried deeper in the sediment (Fig. 7a).

The increase in Fe lability through benthic cycling, also called "rejuvenation", has been shown to be an important pathway for bioavailable iron production in continental margin sediments ${ }^{55}$. A similar pattern of increasing labile iron content was found in a transect from the shelf towards the deepest parts of the Guaymas Basin in the central Gulf of California ${ }^{56}$. The mechanism for this pattern was ascribed to various possible processes and partially to benthic cycling by microorganisms; however, there were numerous $\mathrm{Fe}$ sources, making it difficult to pinpoint a dominant process $^{56}$. The unique situation of a clearly defined major source of iron (the glaciers) makes glaciated fjords ideal for investigating benthic iron cycling processes. We propose that the increasing intensity of benthic iron cycling is due to an increased amount of labile organic carbon and time before burial, which together contributes to the increases of $\mathrm{FeA}$ and FeM from fjord head to mouth. The steep gradients of FeA and FeM are produced by 

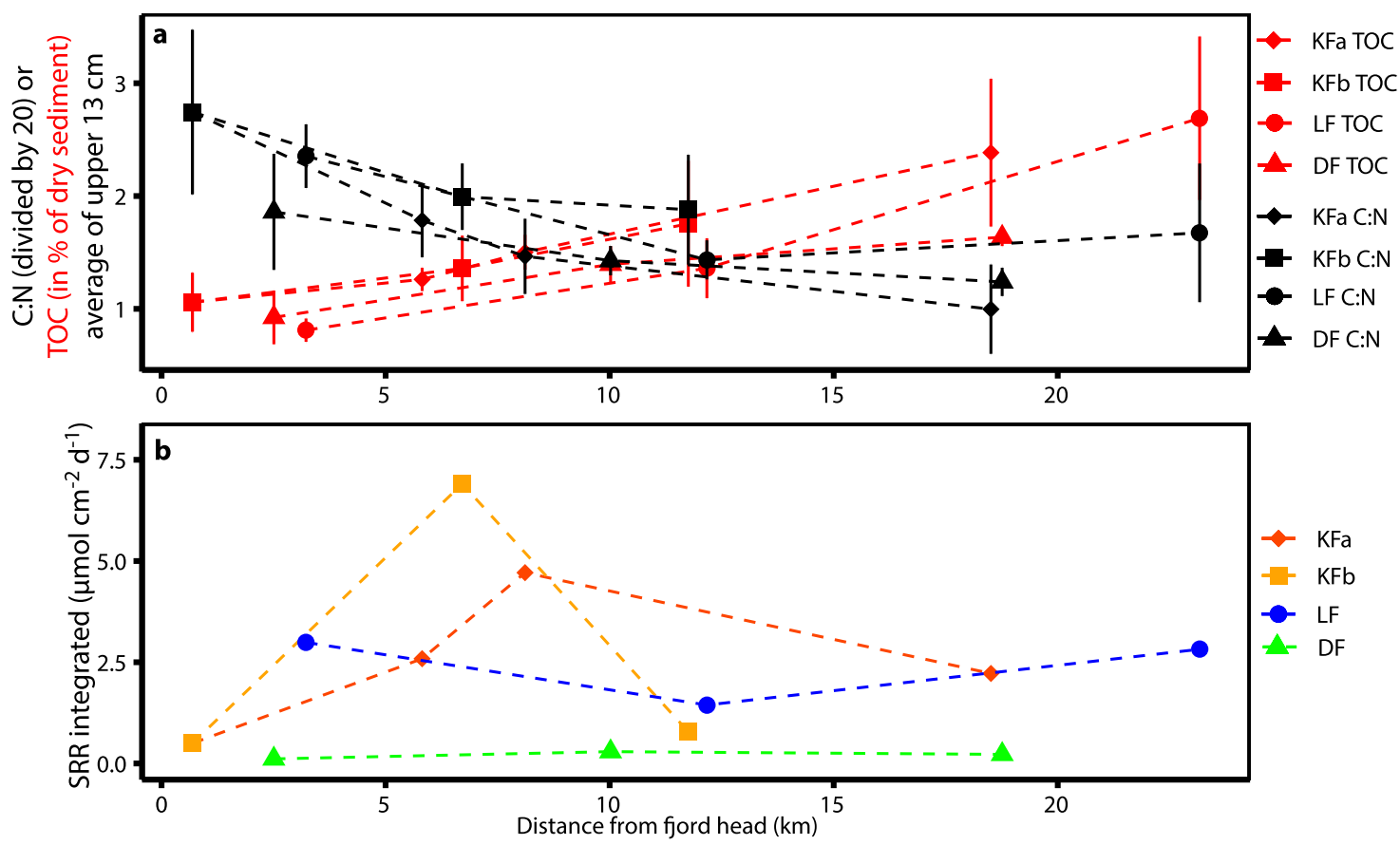

Fig. 6 Total organic carbon (TOC), carbon to nitrogen (C:N) ratios, and integrated sulfate reduction rates (SRR) over distance from the fjord head. a Average of C:N values and TOC in the upper $13 \mathrm{~cm}$ of the sediment over distance from the fjord head. Error bars show SD. $\mathbf{b}$ Depth-integrated SRR over distance from the fjord head.

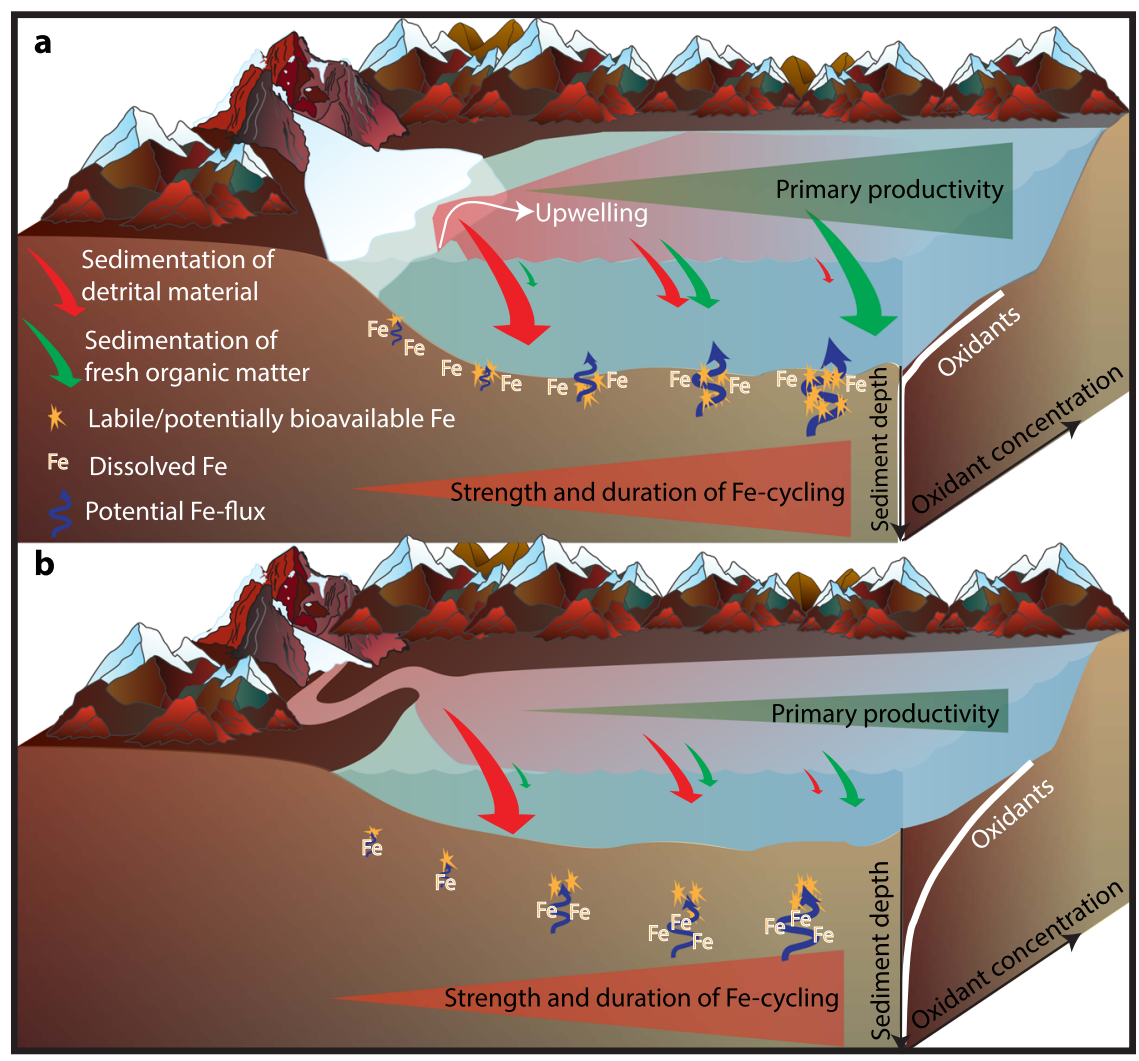

Fig. 7 Schematic comparison of current and future scenarios. The strength of the processes is indicated by symbol/arrow size. a Fe cycling in a fjord with a marine-terminating glacier (current scenario) and $\mathbf{b}$ with a land-terminating glacier (future scenario). Fe-cycling is impacted by the gradients of input of detrital material and fresh organic matter. Symbol descriptions in panel a also apply to (b). 
recycling of glacial $\mathrm{Fe}$ within the sediment and not derived directly from glacial sources. These gradients of FeA and FeM show that proximity to the marine-terminating glacier front is significant for iron cycling and the production of potentially bioavailable iron, making these processes sensitive to future glacial retreat.

The impact of glacial retreat on FeA and FeM distribution. The general pattern of increasing amount and lability of FeA and FeM with distance from the fjord head was also observed in Dicksonfjorden, which is fed by land-terminating glaciers only (Fig. 1). The amount of FeA was only about half of what was found in Kongsfjorden and Lilliehöökfjorden at similar distances from the fjord head (Fig. 3a), probably because of the lower amount of FeA present in particulates in the plume at the head of Dicksonfjorden. However, the lability of FeA was within the same range as for Kongsfjorden and Lilliehöökfjorden (Fig. 3b), despite the lability in the plume at the head of Dicksonfjorden being much lower compared to the average of the glacial source samples from Kongsfjorden (Supplementary Table 1). We propose that, similar to Kongsfjorden and Lillihöökfjorden, benthic cycling is mainly responsible for the increase in the amount and lability of FeA from head to mouth in Dicksonfjorden. In contrast to Lilliehöökfjorden and Kongsfjorden, where the amount of FeA peaked at the sediment surface, the maximum concentration of FeA was never found at the sediment surface in Dicksonfjorden (Fig. 5). At station DF1, the amount of FeA did not change significantly over sediment depth, and at station DF3 and DF5 the maximum concentration of $\mathrm{FeA}$ was found at $3-4$ and $6-8 \mathrm{~cm}$ sediment depth with 38.3 and $70.7 \mu \mathrm{mol} \mathrm{g} \mathrm{dw}^{-1}$, respectively (Fig. 5). We conclude that the production of FeA is not only independent of bedrock lithology but also of the glacial regime. The specific depth-distribution of FeA and FeM that we found in Dicksonfjorden likely attenuates the recycling of potentially bioavailable iron to the water column.

The subsurface peaks of FeA in Dicksonfjorden are likely caused by deeper penetration of oxidants (such as oxygen, nitrate, or Mn(IV)-oxides; Supplementary Table 4), leading to the oxidation of $\mathrm{dFe}(\mathrm{II})$ producing authigenic FeA. This is further evidence that $\mathrm{FeA}$ is mainly authigenic and not a function of the fine-grained and labile material getting transported furthest or produced by cycling during transport in the water column. The presence of oxidants is evident from the absence of dissimilatory sulfate reduction, $\mathrm{dFe}(\mathrm{II})$, and $\mathrm{dMn}$ just above the depth where the maximum amount of FeA was found at station DF3 and DF5 (Fig. 5, Supplementary Fig. 8). This indicates that $\mathrm{dFe}(\mathrm{II})$ and $\mathrm{dMn}$ were oxidized within the top $3-5 \mathrm{~cm}$ of the sediment and could not reach the sediment surface at these stations. At station DF1, low SRR $\left(<1 \mathrm{nmol} \mathrm{cm}{ }^{-3} \mathrm{~d}^{-1}\right)$ and $\mathrm{dMn}$ were found within the upper $4 \mathrm{~cm}$ of the sediment, but no dFe(II) was detected (Supplementary Fig. 8). Again, Dicksonfjorden is in contrast to Kongsfjorden and Lilliehöökfjorden where sulfate reduction was active and $\mathrm{dFe}(\mathrm{II})$ and/or $\mathrm{dMn}$, could be detected within the upper $2 \mathrm{~cm}$ of the sediment at all stations (Figs. 5 and S8). The deeper penetration of oxidants in Dicksonfjorden sediments is likely caused by the generally lower primary productivity in fjords with land-terminating glaciers as they lack glacial upwelling, which is known to entrain nutrient-rich bottom water and transport it up to the photic zone where it supports primary productivity ${ }^{39-41}$. The diminished primary productivity in the Dicksonfjorden water column in the whole fjord leads to a smaller increase in TOC content of the sediment with distance from the head of the fjord compared to Kongsfjorden and Lilliehöökfjorden (Fig. 6a). The lower TOC content at stations further away from the fjord head also led to depth-integrated SRR that remained low over the entire transect (Fig. 6b). As a consequence of low TOC content, the sediment microbial community is less active and oxidants penetrate deeper into the sediment. This prevents $\mathrm{dFe}$ (II) from reaching the sediment surface to fuel authigenic labile Fe(III) production or diffuse into the water column. The observations from Dicksonfjorden suggest that glacial retreat onto land may have the potential to dampen the function of fjord sediments as a source of potentially bioavailable iron, but these results must be confirmed in other fjords with land-terminating glaciers.

The effect of glacial retreat on Fe-export to the water column. Sediments are a dominant source of Fe for waters around coastal Greenland and Svalbard ${ }^{9}$. The production of authigenic, labile Fe (III) at the sediment-water interface ${ }^{57-59}$, and diffusion of $\mathrm{dFe}(\mathrm{II})$ across the sediment-water interface ${ }^{60}$, are important factors for Fe-transfer into the water column. Moreover, bioturbating and bioirrigating benthic fauna are abundant in the outer parts of the fjord ${ }^{54}$ and also contribute to Fe-transfer to the water column. Svalbard fjords are relatively shallow and none of the studied fjords has a pronounced sill near the mouth. Thus, the sediments are exposed to inflowing and/or outflowing seawater ${ }^{49}$, this physical contact of the sediment and the water is a prerequisite for the transfer of potentially bioavailable iron to the water column and the further transport of sediment-derived Fe onto the shelf and open ocean or back into the fjord. Within the fjord, subglacial discharge from marine-terminating glaciers drives the upwelling of $\mathrm{Fe}$ - and macronutrient-rich water, which are essential for phytoplankton growth in glaciated fjords ${ }^{39-41,61}$. The iron enrichment in the upwelled water could at least partially also result from fluxes of $\mathrm{Fe}$ from sediments into the fjord bottom water. We hypothesize that Fe released from sediments into the fjord bottom water is recycled into the photic zone by glacial upwelling. We furthermore hypothesize that there is a decreased potential for Fe-recycling into the photic zone in Dicksonfjorden compared to Kongsfjorden or Lilliehöökfjorden because (i) authigenic $\mathrm{FeA}$ is produced at several $\mathrm{cm}$ sediment depth, (ii) $\mathrm{dFe}$ (II) does not reach the sediment surface and (iii) glacial upwelling is lacking (Fig. 7). This hypothesis highlights the potential changes to fjord Fe cycling as a result of glacial retreat but needs further investigation and studies coupling benthic and pelagic processes are required to confirm this hypothesis. The hypothesized changes to the fjord Fe cycle can further disrupt the carbon cycle, as $\mathrm{Fe}$ is an essential nutrient for phytoplankton in the water column ${ }^{5}$ and $\mathrm{Fe}(\mathrm{III})$ is a significant anaerobic terminal electron acceptor for carbon remineralization in fjord sediments ${ }^{33}$. Therefore, glacial retreat may impact the biological carbon pump in fjords, due to the decreased potential of fjord sediments to function as $\mathrm{Fe}$ sources to the water column and the lack of glacial upwelling.

Fjord sediments are an active interface between land and ocean. To improve our understanding of iron cycling in the ocean and the production of bioavailable iron, it is fundamental to know the sources and fate of iron along the continental margins. We show that glaciers supply large quantities of $\mathrm{Fe}$ to the fjord environment, but the proportion of potentially bioavailable Fe in glacially derived material is low. While fjords were previously expected to reduce glacial iron delivery to the ocean ${ }^{15}$, we show that fjord sediments are a biogeochemically active interface between the land and ocean in which glacially sourced iron is transformed into potentially bioavailable $\mathrm{Fe}$ through benthic cycling. Our results show that surficial sediments near the fjord mouth are enriched in potentially bioavailable Fe that could be a source of iron to the marine shelf and open ocean environments, thereby promoting primary productivity. We furthermore 
highlight the sensitivity of benthic biogeochemical processes in fjord sediments, especially Fe-cycling, to glacial retreat and show that glacial retreat may reduce the sediments ability to serve as a source of iron to the overlying water column.

\section{Methods}

Field sites, sampling, and processing of samples. We sampled fjord sediment and particulate material from glacial sources in three fjords (Kongsfjorden, Lilliehöökfjorden, and Dicksonfjorden) located on the west coast of Spitzbergen, the largest island of the Svalbard archipelago (Fig. 1, Supplementary Table 5 and S6). For a more detailed description of the field, sites see supplemental information.

Fjord Sediment was sampled at 11 sites in Kongsfjorden and nine sites in Lilliehöökfjorden in June and July 2017, two sites in Lilliehöökfjorden in July 2018, and 5 sites in Dicksonfjorden in August 2018 aboard MS Teisten or MS Farm (Supplementary Table 5, Fig. 1). Sediment was retrieved with a Haps corer ${ }^{62}$ and sub-sampled aboard the ship using $2.8 \mathrm{~cm}$ (for SRR measurements) or $6 \mathrm{~cm}$ (for pore water and solid-phase geochemistry) diameter acrylic coring tubes. Sediment was stored at $4{ }^{\circ} \mathrm{C}$ until further processing within 2 days after sampling.

The glacial source material was sampled in Kongsfjorden in June and July 2017, and July 2018. In total, we collected seven pieces from individual icebergs with embedded sediment (Supplementary Fig. 2), four samples of glacial plume water in front of the $\mathrm{KB} / \mathrm{KV}$ calving front, and six samples of meltwater from rivers along the southern and northern shore of Kongsfjorden (Supplementary Table 6, Fig. 1). The material from the meltwater rivers was collected directly at their mouth before entering the fjord. Material from the Dicksonelva plume at the head of Dicksonfjorden was sampled in August 2018 (Supplementary Table 6).

The distances of the stations relative to the main glacial source was determined by geospatial analysis using qGIS (v. 3.10). We used the imagery seen in Fig. 1 to measure the distance from the glacier terminus to the GPS determined sample point. The imagery was collected $\sim 1$ month after our samples were collected and represented the glacial terminus at the time of sample collection.

Processing and subsampling of sediment cores. The $6-\mathrm{cm}$ wide subcores were sliced in an anoxic glove bag under $\mathrm{N}_{2}$ atmosphere $\left(<0.5 \%\right.$ atmospheric $\mathrm{O}_{2}$ concentration, monitored continuously with a trace-range optical oxygen sensor TROXROB10 connected to a Firesting $\mathrm{O}_{2}$-meter, Pyroscience). The cores were processed outside the laboratory at ambient temperature $\left(4-8^{\circ} \mathrm{C}\right)$ inside an anoxic glove bag as described in detail by Michaud et al. ${ }^{31}$. All plasticware used for subsampling was made anoxic by placing the plasticware and an oxygen scrubber (AnaeroGen, ThermoFischer) in a heat-sealed gas-tight plastic bag (Escal Neo, high gas barrier bag, Mitsubishi Gas Chemical Co., Inc.) for at least $24 \mathrm{~h}$. The sediment cores were sliced into $1-3 \mathrm{~cm}$ sections down to a depth of $13 \mathrm{~cm}$. After each section was homogenized, subsamples of sediment were taken for (i) Fe extractions, (ii) determination of porosity, water amount, TOC and TN, and (iii) pore water geochemistry. The subsamples for Fe extractions, porosity, water content, TOC, and TN were immediately frozen at $-20^{\circ} \mathrm{C}$. After closing the centrifuge tubes inside the glove bag under $\mathrm{N}_{2}$ atmosphere, the pore water samples were centrifuged for $15 \mathrm{~min}$ at $3000 \times g$ outside the glove bag. The tubes were immediately returned to the glove bag after centrifugation, and the supernatant was filtered by centrifugation $(5 \mathrm{~min}, 14,100 \times g)$ in spin filters $(0.45 \mu \mathrm{m}$ nylon membrane, Norgen Biotek). For dissolved $\mathrm{Fe}(\mathrm{II})$ and $\mathrm{Mn}$ analysis, an aliquot of the filtrate was acidified ( $\mathrm{HCl}, 1 \mathrm{M}$ final concentration) and the remaining was used for sulfate quantification. All pore water samples were stored at $4{ }^{\circ} \mathrm{C}$ in the dark until analysis.

Processing and subsampling of glacial source material. Particulate material was extracted from plume and river-water by centrifugation $(15 \mathrm{~min}$., $3000 \times g)$. Samples of sediment-loaded icebergs were first rinsed with milliQ water on the exposed surfaces, then we let the ice melt inside a clean plastic bag before centrifugation. In all cases, the pellets were collected and frozen at $-20^{\circ} \mathrm{C}$ until analysis.

Pore water chemistry. Dissolved Fe(II) and Mn in the pore water were measured spectrophotometrically by the ferrozine assay ${ }^{63}$ and the formaldoxime assay, respectively. The formalodxime assay was adapted according to Otte ${ }^{64}$ to exclude interference from high $\mathrm{Fe}^{2+}$ concentration in the sample. Both assays were performed in 96-well plates and the absorbance was measured at $562 \mathrm{~nm}$ for Fe(II) and $450 \mathrm{~nm}$ for Mn with a plate reader (FLUOstarOmega, BMG Labtech). Sulfate concentration in pore water was quantified on 1:100 diluted samples using suppressed ion chromatography (Dionex).

Sulfate reduction rate measurements. Sulfate reduction rates $\left(\mathrm{SRR}, \mathrm{nmol} \mathrm{cm}{ }^{-3}\right.$ $\mathrm{d}^{-1}$ ) were determined by injecting ${ }^{35} \mathrm{SO}_{4}{ }^{2-}$ into intact, $20-25 \mathrm{~cm}$ long, $2.8 \mathrm{~cm}$ diameter sediment cores ${ }^{65}$. Fifty kBq of carrier-free ${ }^{35} \mathrm{~S}_{-} \mathrm{SO}_{4}{ }^{2-}$ was injected at $1-\mathrm{cm}$ depth intervals through ports sealed with polyurethane-based elastic sealant $\left(\right.$ Sikaflex $-11 \mathrm{FC}^{+}$, Sika) ${ }^{66}$. After $10-14 \mathrm{~h}$ of incubation at near in situ temperature $\left(2{ }^{\circ} \mathrm{C}\right)$, the cores were sliced in $1-\mathrm{cm}$ sections, which were added immediately to 10 $\mathrm{ml}$ of $10 \%$ zinc acetate and homogenized by vortexing. The zinc acetate-fixed samples were stored at $-20{ }^{\circ} \mathrm{C}$ until analysis. The cold chromium method ${ }^{66}$ was used to separate radiolabeled total reduced inorganic sulfur (TRIS) from the sample and the evolved $\mathrm{H}_{2} \mathrm{~S}$ was trapped as $\mathrm{Zn}^{35} \mathrm{~S}$ in $5 \mathrm{~mL}$ of $5 \%$ zinc acetate solution. Scintillation counting was used to analyze the radioactivity in the sulfate and TRIS pools and sulfate reduction rates were calculated according to Jørgensen ${ }^{65}$. To determine the water content and porosity of the sediment, required for calculation of SRR, the weight loss of a known volume of sediment after drying to constant weight at $105^{\circ} \mathrm{C}$ was determined. Some of the SRR data is already published in a recently accepted manuscript ${ }^{67}$. For which stations this is the case is stated in Supplementary Table 5 .

TOC and TN analysis. For TOC and TN measurements, sediment was dried at $105^{\circ} \mathrm{C}$ and powdered using a planetary micro mill (Pulverisette 23, Fritsch). After acidification with $\mathrm{HCl}$ to remove inorganic carbon and washing steps with $\mathrm{MQ}$ water to remove additional salt from the $\mathrm{HCl}$, the powdered sediment was dried again and the carbon and nitrogen content and isotopic composition were measured with an elemental analyzer (Thermo Fisher Scientific Flash EA 1112) coupled to an IRMS.

Sequential endpoint Fe extractions. Sequential endpoint extractions with $\mathrm{HCl}$, to separate the poorly crystalline $\left(0.5 \mathrm{M} \mathrm{HCl}, 1 \mathrm{~h}, 20^{\circ} \mathrm{C}\right)$ from the crystalline $(6 \mathrm{M}$ $\mathrm{HCl}, 24 \mathrm{~h}, 70^{\circ} \mathrm{C}$ ) $\mathrm{Fe}(\mathrm{II})$ and $\mathrm{Fe}(\mathrm{III})$ in the sediments and the glacial source samples, were done as described by Laufer et al. ${ }^{26}$. Fe(II) and total Fe concentrations in the extracts were determined spectrophotometrically by the ferrozine assay ${ }^{63}$. For total $\mathrm{Fe}$ concentrations, all $\mathrm{Fe}$ (III) was reduced to $\mathrm{Fe}(\mathrm{II})$ with the reductant hydroxylamine hydrochloride ( $\mathrm{HAHCl}, 10 \% \mathrm{w} / \mathrm{v}$ in $1 \mathrm{M} \mathrm{HCl}$ ) before the assay. Fe(III) was calculated from the difference between $\mathrm{Fe}(\mathrm{II})$ and total Fe concentrations.

Ascorbate time-course extractions. Ascorbate extractable $\mathrm{Fe}(\mathrm{FeA})$ was determined in ascorbate Fe reduction time-course extractions ${ }^{42,43}$. These experiments were conducted in $100 \mathrm{ml}$ Schott bottles, equipped with four-port Schott Duran ${ }^{\circledast}$ Pressure Plus screw caps. Of the screw caps, two ports were used for flushing the bottles with $\mathrm{N}_{2}$. One port was used for the injection of the extraction solution. These three ports were equipped with tygon tubings and three-way valves. The last port was used for fluid sampling during the extraction and was equipped with a Rhizon soil moisture sampler $(0.15 \mu \mathrm{m}$ pore size, Rhizosphere Research Products) This setup allowed us to follow the time-dependent dissolution of Fe during the extractions

Inside an anoxic glove bag, the frozen sediment was thawed for the extractions $\left(\mathrm{O}_{2}<0.5 \%\right.$ atmospheric concentration). Between 0.5 and $1 \mathrm{~g}$ of sediment was weighed into the Schott bottles, the bottles were closed inside the anoxic glove bags and immediately flushed with $\mathrm{N}_{2}$ after they were taken out of the glove bag. After 3 min of flushing with $\mathrm{N}_{2}, 100 \mathrm{ml}$ of extraction solution, containing $0.6 \mathrm{M}$ sodium bicarbonate, $0.17 \mathrm{M}$ sodium citrate, and $0.1 \mathrm{M}$ sodium citrate, $\mathrm{pH} 7.5$ was added through one port. Stirring with a Teflon-coated magnetic stir bar was started and continued throughout the extraction. Immediately after adding the extraction solution, samples for determining the dissolved Fe(II) concentration were taken through the Rhizon and fixed in $1 \mathrm{M} \mathrm{HCl}$ (final concentration). Sampling continued in intervals with increasing length, starting with $5 \mathrm{~min}$ at the beginning, increasing to 10,20 , and $30 \mathrm{~min}$, and finally every $1-2 \mathrm{~h}$ within the first $400-500$ min. Sampling was continued the next day until a stable Fe(II) concentration was reached (which was the case after a maximum $32 \mathrm{~h}$ ). Fe(II) concentrations were quantified using the ferrozine assay as described above for the pore water samples.

A reactive continuum model (ref. ${ }^{42}$, Eq. 1 ) was used to calculate the amount of extractable iron $\left(\mathrm{M}_{(0)} \mu \mathrm{mol} \mathrm{g} \mathrm{dw}^{-1}\right)$, the reducibility of FeA (v/a, s$\left.{ }^{-1}\right)$, the composition of $\mathrm{FeA}(1+1 / \mathrm{v})$, and lability of FeA (initial rate of reduction, $\mu \mathrm{mol} g$ $\mathrm{dw}^{-1} \mathrm{~s}^{-1}$ ) as described in detail by Laufer et al. ${ }^{26}$ (Eq.1, Table 1).

$$
\frac{\mathrm{J}}{\mathrm{M}_{(0)}}=\frac{\mathrm{v}}{\mathrm{a}}\left(\frac{\mathrm{M}_{(\mathrm{t})}}{\mathrm{M}_{(0)}}\right)^{1+\frac{1}{\mathrm{v}}}
$$

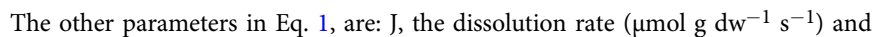
$\mathrm{M}_{(\mathrm{t})}$, which is the ascorbate extractable Fe(III) left in the sediment at time $\mathrm{t}$ ( $\mu$ mol $\mathrm{g}$ $\left.\mathrm{dw}^{-1}\right)$. The time-dependent development of $\mathrm{M}_{(\mathrm{t})}$ is described by Eq. 2 :

$$
M_{(t)}=M_{(0)}\left(\frac{a}{a+t}\right)^{v}
$$

We defined $\mathrm{M}_{(0)}$ as the maximum amount of Fe released into the solution at the end of the extraction. Using Eq. 2, the parameters a and v were fitted to Eq. 2 by applying the nonlinear least squares (nls) function in R. The parameters v/a and 1 $+1 / \mathrm{v}$ were calculated based on the fitted $\mathrm{v}$ and $\mathrm{a}$. The amount of Fe dissolved at any time point $\left(\mathrm{Fe}_{\mathrm{d}}(\mathrm{t})\right.$ in $\left.\mu \mathrm{mol} \mathrm{g} \mathrm{dw}^{-1}\right)$ was calculated according to Eq. 3 , in order to visualize the model results of the release of $\mathrm{Fe}(\mathrm{II})$ into the solution over time.

$$
\mathrm{Fe}_{\mathrm{d}}(\mathrm{t})=\mathrm{M}_{(0)}-\mathrm{M}_{(\mathrm{t})}
$$

The initial rate of $\mathrm{Fe}(\mathrm{II})$ dissolution per $\mathrm{g} \mathrm{dw}^{-1}$ (reducibility of $\mathrm{FeA}$ ) was calculated by multiplying the apparent rate constant v/a with $\mathrm{M}_{(0)}$.

Statistical tests on the significance of the increase in $\mathrm{M}_{(0)}$ and initial rates in the surface sediment with increasing distance from the glacial source were performed by linear regression analysis in $\mathrm{R}$. 
The $\mathrm{R}$ code for these calculations can be found in a github repository (https:// github.com/klaufer-meiser/Time-course_extractions_code).

Microbial time-course extractions. A pure culture of Shewanella frigidimarina DSM- $12253^{68}$ was used to determine microbially reducible $\mathrm{Fe}(\mathrm{FeM})$ in timecourse extractions. Pre- cultures of S. frigidimarina were grown aerobically on fullstrength Luria-Bertani (LB) medium, where $\mathrm{NaCl}$ was exchanged with artificial seawater (ASW) salts ( $\mathrm{NaCl}, 27.5 \mathrm{gl}^{-1} ; \mathrm{MgCl}_{2} * 6 \mathrm{H}_{2} \mathrm{O}, 5.38 \mathrm{gl}^{-1} ; \mathrm{MgSO}_{4}{ }^{*} 7 \mathrm{H}_{2} \mathrm{O}$, $6.78 \mathrm{~g} \mathrm{l}^{-1} ; \mathrm{KCl}, 0.72 \mathrm{~g} \mathrm{l}^{-1} ; \mathrm{CaCl}_{2}{ }^{*} 2 \mathrm{H}_{2} \mathrm{O}, 1.4 \mathrm{gl}^{-1} ; \mathrm{NH}_{4} \mathrm{Cl}, 1 \mathrm{gl}^{-1} ; \mathrm{K}_{2} \mathrm{HPO}_{4}, 0.05 \mathrm{gl}$ ${ }^{-1}$ ). From one colony of the LB plate, an overnight culture was grown in $10 \mathrm{ml}$ liquid LB ASW at $20^{\circ} \mathrm{C}$. From the actively growing overnight culture, larger volumes (200-300 ml) of liquid LB-ASW were inoculated and grown overnight to an OD of 2-2.5, which meant the cultures were in late exponential phase (which was the case after ca. $16 \mathrm{~h}$ ). For the experiments, concentrated S. frigidimarina cultures were prepared by washing the cultures three times with ASW by centrifuging ( $20 \mathrm{~min}, 3000 \times \mathrm{g}$ ), after each centrifugation the supernatant was discarded and the pellet was resuspended in fresh ASW. Next, the culture was resuspended in ASW in a serum vial to a cell density of ca. $3 \times 10^{10} \mathrm{cells} \mathrm{ml}^{-1}$ and the concentrated culture was made anoxic by bubbling with sterile-filtered $\mathrm{N}_{2}(0.22 \mu \mathrm{m}$ pore size).

Inside an anoxic glove bag $\left(\mathrm{N}_{2}\right.$ atmosphere, $\mathrm{O}_{2}<0.5 \%$ atmospheric concentration) between 0.1 and $0.4 \mathrm{~g}$ of the sediment was weighed into $15 \mathrm{ml}$ Hungate tubes and the tubes were closed with a butyl stopper and screw cap. Afterwards, $9 \mathrm{ml}$ of anoxic ASW, amended with Na-bicarbonate buffer $(22 \mathrm{mM})$, Na-citrate $(170 \mathrm{mM})$, Na-lactate $(10 \mathrm{mM})$ and Na-molybdate $(20 \mathrm{mM})$, adjusted to $\mathrm{pH} 7.5$, was added. The Headspace was flushed with $\mathrm{N}_{2} / \mathrm{CO}_{2}$ (80:20). Then, $1 \mathrm{ml}$ concentrated S. frigidimarina culture was added to reach a final cell concentration of ca. $3 \times 10^{9}$ cells ml ${ }^{-1}$. All extractions were performed in triplicates while a fourth replicate remained as an uninoculated control and served as a measure of native $\mathrm{Fe}$ (III)-reducer population activity in the sediment.

The microbial extractions were performed on a horizontal shaker at $20^{\circ} \mathrm{C}$ in the dark, to prevent photoreduction. Sampling was performed with a $\mathrm{N}_{2}$-flushed syringe with a thick needle $(0.5 \times 25 \mathrm{~mm})$. One-hundred $\mu \mathrm{l}$ of the sample were added to $900 \mu \mathrm{l}$ of $1 \mathrm{M} \mathrm{HCl}$ and acid-extraction was performed for $1 \mathrm{~h}$ on a horizontal shaker. The acid-extraction was stopped by centrifugation $(5 \mathrm{~min}$, $12,100 \times g$ ) and the supernatant was used for $\mathrm{Fe}(\mathrm{II})$ analysis with the ferrozine assay ${ }^{63}$. Samples were taken directly before and after the addition of the $S$. frigidimarina culture and the $\mathrm{Fe}(\mathrm{II})$ concentration was followed over time until it reached a constant value. Sampling intervals were between $10 \mathrm{~min}$ and $300 \mathrm{~h}$, and were chosen depending on the observed $\mathrm{Fe}(\mathrm{II})$ reduction rates. Uninoculated controls were sampled in parallel throughout the duration of the experiment.

The parameters $\mathrm{M}_{(0)}$ (amount of FeM), v/a (lability of FeM), $1+1 / \mathrm{v}$ (the composition of $\mathrm{FeM}$ ) and initial rates (reducibility of $\mathrm{FeM}$ ) were determined with the same equations as described above for the ascorbate time-course extractions.

Particle size analysis. Particle size analysis was performed at Binghamton University's Analytical and Diagnostics Laboratory. Approximately $1 \mathrm{~g}$ of bulk sample was gently disaggregated and treated for the removal of organic matter with $\sim 20 \mathrm{ml}$ of $27 \%$ hydrogen peroxide $\left(\mathrm{H}_{2} \mathrm{O}_{2}\right)$ in hot water bath. Smear slides of treated samples were analyzed under a binocular microscope in order to assess for the presence of biogenic components. As no biogenic material could be detected on the smear slides, samples were then treated with $10 \%$ sodium hexametaphosphate and shaken for $12 \mathrm{~h}$ prior to analysis on the Beckman Coulter LS 13320 Laser Diffraction Analyzer.

57Fe Mössbauer spectroscopy. Mössbauer spectroscopy analysis was performed at the Center for Applied Geosciences at the University of Tübingen. Freeze-dried samples were loaded into Plexiglas holders $\left(\operatorname{area} 1 \mathrm{~cm}^{2}\right.$ ), forming a thin disc, within an anoxic glovebox $\left(100 \% \mathrm{~N}_{2}\right)$. Sample holders were transported to the instrument within airtight bottles which were only opened immediately prior to loading into a closed-cycle exchange gas cryostat (Janis cryogenics) under a backflow of He to minimize exposure to ambient air. Spectra were collected at 77 and $5 \mathrm{~K}$ using a constant acceleration drive system (WissEL) in transmission mode with a ${ }^{57} \mathrm{Co} / \mathrm{Rh}$ source. All spectra were calibrated against a $7-\mu \mathrm{m}$ thick $\alpha^{-57} \mathrm{Fe}$ foil that was measured at room temperature. The analysis was carried out using Recoil (University of Ottawa) and the Voigt Based Fitting (VBF) routine ${ }^{69}$. The half width at half maximum (HWHM) was constrained to $0.138 \mathrm{~mm} \mathrm{~s}^{-1}$ during fitting.

\section{Data availability}

The authors declare that all the data supporting the findings of this study and all source data are available in the article and its Supplementary Information file. Any further information is available from the corresponding author upon request.

\section{Code availability}

The $\mathrm{R}$ code used for calculating parameters of the kinetic extractions can be found in a github repository (https://github.com/klaufer-meiser/Time-course_extractions_code) ${ }^{70}$.
Received: 7 August 2020; Accepted: 28 January 2021; Published online: 01 March 2021

\section{References}

1. Dethloff, K., Handorf, D., Jaiser, R., Rinke, A. \& Klinghammer, P. Dynamical mechanisms of Arctic amplification. Ann. N. Y. Acad. Sci. 1436, 184-194 (2019).

2. Włodarska-Kowalczuk, M. et al. Organic carbon origin, benthic faunal consumption, and burial in sediments of Northern Atlantic and Arctic Fjords (60-81ํN). J. Geophys. Res. Biogeosci. 124, 3737-3751 (2019).

3. Cui, X., Bianchi, T. S., Savage, C. \& Smith, R. W. Organic carbon burial in fjords: terrestrial versus marine inputs. Earth Planet. Sci. Lett. 451, 41-50 (2016).

4. Bianchi, T. S. et al. Fjords as aquatic critical zones (ACZs). Earth-Sci. Rev. 203, 103145 (2020)

5. Tagliabue, A. et al. The integral role of iron in ocean biogeochemistry. Nature 543, 51-59 (2017)

6. Klunder, M. B. et al. Dissolved iron in the Arctic shelf seas and surface waters of the central Arctic Ocean: impact of Arctic river water and ice-melt. J. Geophys. Res. Ocean. 117, 1-18 (2012).

7. Rijkenberg, M. J. A., Slagter, H. A., Rutgers van der Loeff, M., van Ooijen, J. \& Gerringa, L. J. A. Dissolved Fe in the deep and upper Arctic Ocean with a focus on Fe limitation in the Nansen Basin. Front. Mar. Sci. 5, 1-14 (2018).

8. Ryan-Keogh, T. J. et al. Spatial and temporal development of phytoplankton iron stress in relation to bloom dynamics in the high-latitude North Atlantic Ocean. Limnol. Oceanogr. 58, 533-545 (2013).

9. Krisch, S. et al. The influence of Arctic Fe and Atlantic fixed $\mathrm{N}$ on summertime primary production in Fram Strait, North Greenland Sea. Sci. Rep. 10, 1-10 (2020).

10. Wadham, J. L. et al. The potential role of the Antarctic Ice Sheet in global biogeochemical cycles. Earth Environ. Sci. Trans. R. Soc. Edinb. 104, 55-67 (2013).

11. Raiswell, R. et al. Contributions from glacially derived sediment to the global iron (oxyhydr) oxide cycle: implications for iron delivery to the oceans. Geochim. Cosmochim. Acta 70, 2765-2780 (2006).

12. Raiswell, R. \& Canfield, D. E. The iron biogeochemical cycle past and present. Geochem. Perspect. 1, 1-2 (2012).

13. Bhatia, M. P. et al. Greenland meltwater as a significant and potentially bioavailable source of iron to the ocean. Nat. Geosci. 6, 274-278 (2013).

14. Meslard, F., Bourrin, F., Many, G. \& Kerhervé, P. Suspended particle dynamics and fluxes in an Arctic fjord (Kongsfjorden, Svalbard). Estuar. Coast. Shelf Sci. 204, 212-224 (2018).

15. Raiswell, R. et al. Iron in glacial systems: speciation, reactivity, freezing behaviour and alteration during transport. Front. Earth Sci. 6, 1-17 (2018).

16. Zhang, R. et al. Transport and reaction of iron and iron stable isotopes in glacial meltwaters on Svalbard near Kongsfjorden: From rivers to estuary to ocean. Earth Planet. Sci. Lett. 424, 201-211 (2015).

17. Wehrmann, L. M. et al. Iron and manganese speciation and cycling in glacially influenced high-latitude fjord sediments (West Spitsbergen, Svalbard): evidence for a benthic recycling-transport mechanism. Geochim. Cosmochim. Acta 141, 628-655 (2014).

18. Wehrmann, L. M. et al. Iron-controlled oxidative sulfur cycling recorded in the distribution and isotopic composition of sulfur species in glacially influenced fjord sediments of west Svalbard. Chem. Geol. 466, 678-695 (2017)

19. Li, X. et al. Dissolved iron supply from Asian Glaciers: local controls and a regional perspective. Glob. Biogeochem. Cycles 33, 1223-1237 (2019).

20. Shoenfelt, E. M. et al. High particulate iron(II) content in glacially sourced dusts enhances productivity of a model diatom. Sci. Adv. 3, 1-10 (2017).

21. Roden, E. E. Microbiological Controls on Geochemical Kinetics 1: Fundamentals and Case Study on Microbial Fe(III) Oxide Reduction, In Kinetics of Water-Rock Interaction (Springer, 2005).

22. Raiswell, R., Vu, H. P., Brinza, L. \& Benning, L. G. The determination of labile Fe in ferrihydrite by ascorbic acid extraction: Methodology, dissolution kinetics and loss of solubility with age and de-watering. Chem. Geol. 278, 70-79 (2010).

23. Raiswell, R. et al. Potentially bioavailable iron delivery by iceberg-hosted sediments and atmospheric dust to the polar oceans. Biogeoscience 13, 3887-3900 (2016).

24. Yoshida, M. et al. Effect of aging time on the availability of freshly precipitated ferric hydroxide to coastal marine diatoms. Mar. Biol. 149, 379-392 (2006).

25. Postma, D. \& Jakobsen, R. Redox zonation: equilibrium constraints on the Fe (III)/SO 4-reduction interface. Geochim. Cosmochim. Acta 60, 3169-3175 (1996). 
26. Laufer, K., Michaud, A., Røy, H. \& Jørgensen, B. Reactivity of iron minerals in the seabed towards microbial reduction - a comparison of different extraction techniques. Geomicrobiol. J. 37, 170-189 (2020).

27. Herbert, L. C. et al. Glacial controls on redox-sensitive trace element cycling in Arctic fjord sediments (Spitsbergen, Svalbard). Geochim. Cosmochim. Acta 271, 33-60 (2020)

28. Raiswell, R., Benning, L. G., Tranter, M. \& Tulaczyk, S. Bioavailable iron in the Southern Ocean: the significance of the iceberg conveyor belt. Geochem. Trans. 9, 7 (2008).

29. Hopwood, M. J. \& Cantoni, C. The heterogeneous nature of Fe delivery from melting icebergs. Geochem. Perspect. Lett. 3, 200-209 (2017).

30. Hawkings, J. R. et al. Ice sheets as a significant source of highly reactive nanoparticulate iron to the oceans. Nat. Commun. 5, 1-8 (2014).

31. Michaud, A. B. et al. Glacial influence on the iron and sulfur cycles in Arctic fjord sediments (Svalbard). Geochim. Cosmochim. Acta 280, 423-440 (2020).

32. Mejia, J., Roden, E. E. \& Ginder-Vogel, M. Influence of oxygen and nitrate on Fe (hydr)oxide mineral transformation and soil microbial communities during redox cycling. Environ. Sci. Technol. 50, 3580-3588 (2016).

33. Melton, E. D., Swanner, E. D., Behrens, S., Schmidt, C. \& Kappler, A. The interplay of microbially mediated and abiotic reactions in the biogeochemical Fe cycle. Nat. Rev. Microbiol 12, 797-808 (2014).

34. Bonneville, S., Van Cappellen, P. \& Behrends, T. Microbial reduction of iron (III) oxyhydroxides: effects of mineral solubility and availability. Chem. Geol. 212, 255-268 (2004)

35. Chan, C. S., Fakra, S. C., Edwards, D. C., Emerson, D. \& Banfield, J. F. Iron oxyhydroxide mineralization on microbial extracellular polysaccharides. Geochim. Cosmochim. Acta 73, 3807-3818 (2009).

36. Zhao, L., Dong, H., Edelmann, R. E., Zeng, Q. \& Agrawal, A. Coupling of Fe (II) oxidation in illite with nitrate reduction and its role in clay mineral transformation. Geochim. Cosmochim. Acta 200, 353-366 (2017).

37. Shi, F. et al. Clay minerals in Arctic Kongsfjorden surface sediments and their implications on provenance and paleoenvironmental change. Acta Oceanol. Sin. 37, 29-38 (2018).

38. Milner, A. M. et al. Glacier shrinkage driving global changes in downstream systems. Proc. Natl Acad. Sci. USA 114, 9770-9778 (2017).

39. Hopwood, M. J. et al. Non-linear response of summertime marine productivity to increased meltwater discharge around Greenland. Nat. Commun. 9, 1-9 (2018).

40. Meire, L. et al. Marine-terminating glaciers sustain high productivity in Greenland fjords. Glob. Chang. Biol. 23, 5344-5357 (2017).

41. Hopwood, M. et al. How does glacier discharge affect marine biogeochemistry and primary production in the Arctic? Cryosph. Discuss 14, 1347-1383 (2019).

42. Postma, D. The reactivity of iron oxides in sediments: a kinetic approach. Geochim. Cosmochim. Acta 57, 5027-5034 (1993).

43. Hyacinthe, C., Bonneville, S. \& Van Cappellen, P. Reactive iron(III) in sediments: Chemical versus microbial extractions. Geochim. Cosmochim. Acta 70, 4166-4180 (2006).

44. Dallmann, W. K. Geoscience Atlas of Svalbard. (Norsk polarinstitutt, 2015).

45. Kvam, M. H. Deposits and Processes on the Tide-influenced Fjord-Head Delta in Dicksonfjorden, Svalbard. Masters Thesis, UiT The Arctic University of Norway (2018)

46. Revels, B. N., Ohnemus, D. C., Lam, P. J., Conway, T. M. \& John, S. G. The isotopic signature and distribution of particulate iron in the North Atlantic Ocean. Deep. Res. Part II Top. Stud. Oceanogr. 116, 321-331 (2015).

47. Abadie, C., Lacan, F., Radic, A., Pradoux, C. \& Poitrasson, F. Iron isotopes reveal distinct dissolved iron sources and pathways in the intermediate versus deep Southern Ocean. Proc. Natl Acad. Sci. USA 5, 858-863 (2017).

48. Bennett, P. C., Rogers, J. R., Choi, W. J. \& Hiebert, F. K. Silicates, silicate weathering, and microbial ecology. Geomicrobiol. J. 18, 3-19 (2001).

49. Svendsen, H. et al. The physical environment of Kongsfjorden - Krossfjorden, an Arctic fjord system in Svalbard. Polar Res. 21, 133-166 (2002).

50. Hop, H. et al. The marine ecosystem of Kongsfjorden, Svalbard. Polar Res. 21, 167-208 (2002).

51. Kim, J. H. et al. Large ancient organic matter contributions to Arctic marine sediments (Svalbard). Limnol. Oceanogr. 56, 1463-1474 (2011).

52. Arndt, S. et al. Quantifying the degradation of organic matter in marine sediments: a review and synthesis. Earth-Sci. Rev. 123, 53-86 (2013).

53. Pelikan, C. et al. Glacial runoff promotes deep burial of sulfur cycling-associated microorganisms in marine sediments. Front. Microbiol. 10, 1-17 (2019).

54. Wlodarska-Kowalczuk, M. \& Pearson, T. H. Soft-bottom macrobenthic faunal associations and factors affecting species distributions in an Arctic glacial fjord (Kongsfjord, Spitsbergen). Polar Biol. 27, 155-167 (2004).

55. Beam, J. P. et al. Biological rejuvenation of iron oxides in bioturbated marine sediments. ISME J. 12, 1389-1394 (2018).

56. Scholz, F. et al. Shelf-to-basin iron shuttle in the Guaymas Basin, Gulf of California. Geochim. Cosmochim. Acta 261, 76-92 (2019).

57. Schlosser, C. et al. Mechanisms of dissolved and labile particulate iron supply to shelf waters and phytoplankton blooms off South Georgia, Southern Ocean. Biogeoscience 15, 4973-4993 (2018).
58. Lam, P., Heller, M. I., Lerner, P. E., Moffett, J. W. \& Buck, K. Unexpected source and transport of iron from the deep Peru Margin. ACS Earth Sp. Chem. 4, 977-992 (2020)

59. Tessin, A. et al. Arctic continental margin sediments as possible Fe and $\mathrm{Mn}$ sources to seawater as sea ice retreats: Insights from the Eurasian Margin. Glob. Biogeochem. Cycles 34, 1-15 (2020).

60. Klar, J. K. et al. Stability of dissolved and soluble Fe(II) in shelf sediment pore waters and release to an oxic water column. Biogeochemistry 137, 49-67 (2017).

61. Kanna, N., Sugiyama, S., Fukamachi, Y., Nomura, D. \& Nishioka, J. Iron supply by subglacial discharge into a fjord near the front of a marineterminating glacier in northwestern Greenland. Glob. Biogeochem. Cycles 34 e2020GB006567 (2020).

62. Kanneworff, E. \& Nicolaisen, W. The "Haps" a frame-supported bottom corer. Ophelia 10, 119-129 (1973)

63. Stookey, L. L. Ferrozine - a New Spectrophotometric Reagent for Iron. Anal. Chem. 42, 779-781 (1970).

64. Otte, J. M. Iron-cycling microorganisms in marine and freshwater sediments and implications for greenhouse gas emission (Eberhard Karls Universität, 2018).

65. Jørgensen, B. B. A comparison of methods for the quantification of bacterial sulfate reduction in coastal marine sediments. Geomicrobiol. J. 1, 11-27 (1978).

66. Røy, H., Weber, H. S., Tarpgaard, I. H., Ferdelman, T. G. \& Jørgensen, B. B. Determination of dissimilatory sulfate reduction rates in marine sediment via radioactive 35 S tracer. Limnol. Oceanogr. Methods 12, 196-211 (2014).

67. Jørgensen, B. B., Laufer, K., Michaud, A. B. \& Wehrmann, L. M. Biogeochemistry and microbiology of high Arctic marine sediment ecosystems- case study Svalbard fjords. Limnol. Oceanogr. 20, 1-20 (2020).

68. Bowman, J. P. et al. Shewanella gelidimarina sp. nov. and Shewanella frigidimarina sp. nov., novel Antarctic species with the ability to produce eicosapentaenoic acid (20:5 $\omega 3$ ) and grow anaerobically by dissimilatory $\mathrm{Fe}$ (III) reduction. Int. J. Syst. Bacteriol. 47, 1040-1047 (1997).

69. Rancourt, D. G. \& Ping, J. Y. Voigt-based distributions methods for arbitraryshape in Mössbauer spectroscopy static hyperfine parameter. Nucl. Instrum. Methods Phys. Res. B 58, 85-97 (1991).

70. Laufer-Meiser, K. et al. Potentially bioavailable iron produced through benthic cycling in glaciated Arctic fjords of Svalbard, Github, https://doi.org/10.5281/ zenodo.4442467 (2021)

\section{Acknowledgements}

We thank the Alfred Wegener Institute-Institute Paul Emile Victor (AWIPEV) station as well as the Josef Svoboda Station of the University of South Bohemia and staff for housing and excellent logistics support. We furthermore thank MS Farm captain Stig Henningsen and first mate, Reidar Sørensen, as well as MS Teisten captain Roar Strand We appreciate the technical assistance of Karina Bomholt Oest at Aarhus University. This work was supported by the Danish National Research Foundation [DNRF104]; European Research Council [ERC Advanced Grant \#294200 to BBJ]; Danish Council for Independent Research [DFF - 7014-00196 to B.B.J.]; as well as by postdoctoral fellowships from the US-National Science Foundation [EARPF1625158 to A.B.M.], and the German Research Foundation [DFG389371177 to K.L.M.]. The Polar Geospatial Center and Brad Herried provided geospatial support under NSF OPP awards 1043681 and 1559691 and produced maps from ESA remote sensing data. Grain size analysis was supported through funding by Binghamton Universities Analytical and Diagnostics Laboratory (ADL) Small Grant program to M.O.P. We thank all the participants of the 2017 and 2018 Svalbard KOP 56/RiS 10528 expeditions for help with sample collection and providing stimulating discussions. We furthermore would like to thank Martyn Tranter and Mark Hopwood for their valuable input on the manuscript.

\section{Author contributions}

K.L.M. and A.B.M., under the supervision of H.R. and B.B.J., designed the study, performed fieldwork, laboratory measurements of SRR, analyzed data, and wrote the manuscript. K.L.M. performed laboratory measurements and data analysis of Fe and $\mathrm{Mn}$. M.M., J.M.B., and A.K. performed Mössbauer spectroscopy measurements, analyzed Mössbauer spectroscopy data, and wrote the sections regarding Mössbauer spectroscopy. M.O.P. performed particle size measurements, analyzed the data, and wrote the sections regarding particle size analysis. H.R. and B.B.J. performed fieldwork. All authors reviewed the manuscript.

\section{Funding}

Open Access funding enabled and organized by Projekt DEAL.

\section{Competing interests}

The authors declare no competing interests. 


\section{Additional information}

Supplementary information The online version contains supplementary material available at https://doi.org/10.1038/s41467-021-21558-w.

Correspondence and requests for materials should be addressed to K.L.-M.

Peer review information Nature Communications thanks Pier van der Merwe and other, anonymous, reviewers for their contributions to the peer review of this work. Peer review reports are available.

Reprints and permission information is available at http://www.nature.com/reprints

Publisher's note Springer Nature remains neutral with regard to jurisdictional claims in published maps and institutional affiliations. (c) (P) Open Access This article is licensed under a Creative Commons Attribution 4.0 International License, which permits use, sharing, adaptation, distribution and reproduction in any medium or format, as long as you give appropriate credit to the original author(s) and the source, provide a link to the Creative Commons license, and indicate if changes were made. The images or other third party material in this article are included in the article's Creative Commons license, unless indicated otherwise in a credit line to the material. If material is not included in the article's Creative Commons license and your intended use is not permitted by statutory regulation or exceeds the permitted use, you will need to obtain permission directly from the copyright holder. To view a copy of this license, visit http://creativecommons.org/ licenses/by/4.0/.

(C) The Author(s) 2021, corrected publication 2021 